Historic, Archive Document

Do not assume content reflects current scientific knowledge, policies, or practices. 



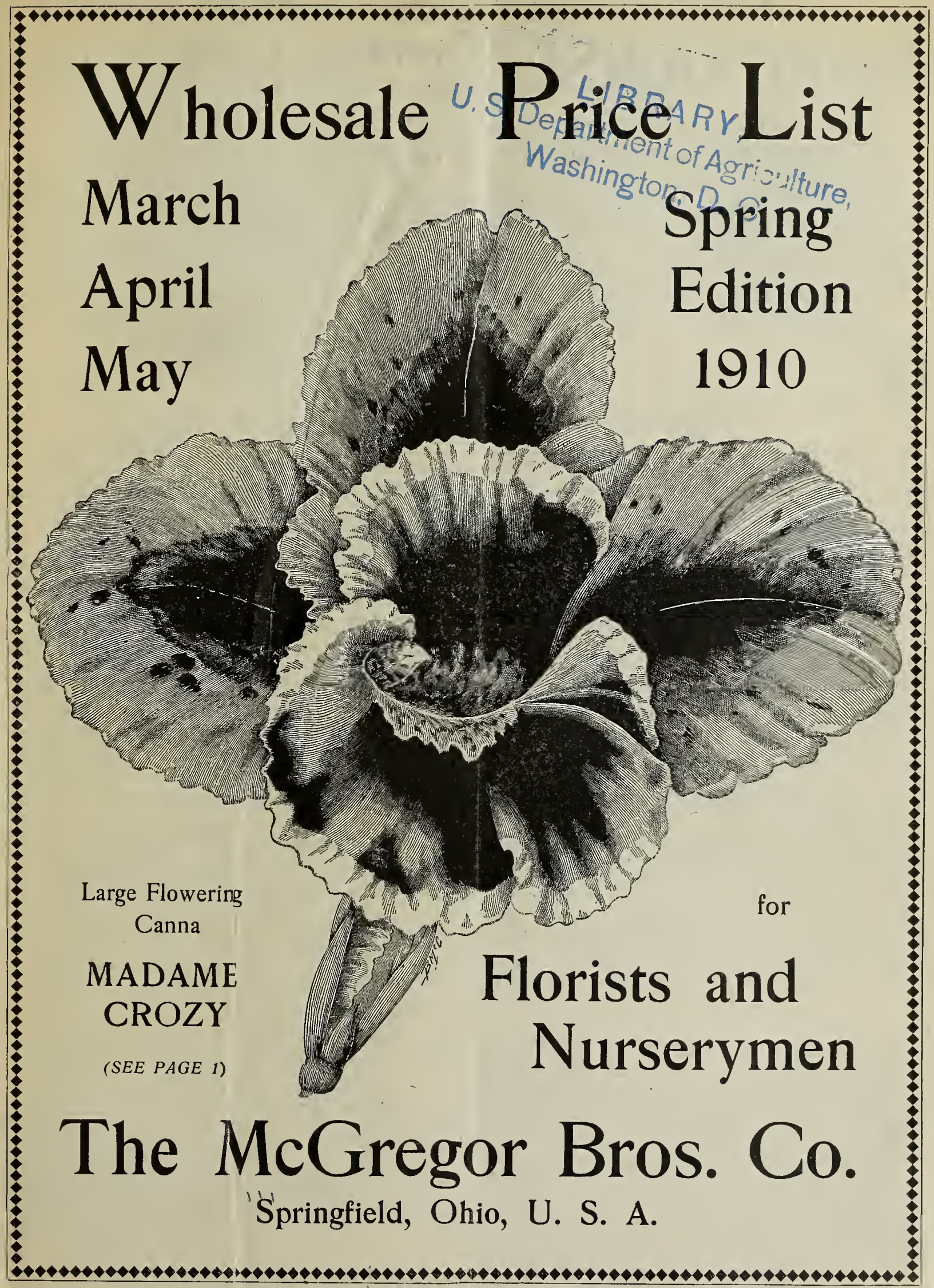




\title{
MCGREG0RS' \\ WHOLESALE PRICE LIST For Florists and Dealers Only
}

\section{Important Information for Correspondents and Customers}

\begin{abstract}
This list cancels all previous offers, and the prices quoted herein are not subject to discounts. Our stock is large and in fine condition. The plants are grown in as low temperature as possible, so that they can be shipped to all parts of the country at all seasons of the year. Our system of packing is so complete that, although we send out hundreds of packages during the coldest winter days, we rarely have a shipment injured when sent by express.

All plants will be forwarded by express unless otherwise ordered Having the rival companies-Adams American, at the lowest possible rates without extra charge. Customers will please say by which line their goods are to be forwarded.
\end{abstract}

\section{OUR FACILITIES FOR TRANSPORTATION}

\author{
Adams \\ Express Companies. \\ American \\ Wells Fargo \\ Pacific \\ Southern \\ United States. \\ Operating Over \\ P., C., C. \& St. L. Ry. (Panhandle Route-Penn. Lines). \\ C., C., C. \& St. L. Ry. (Big Four Route-N. Y. Central Lines). \\ Erie Lines-Nypano Route. \\ Detroit, Toledo \& Ironton Ry \\ Pro-rating with Adams Express. \\ Tcnnage via American Express.
}

\section{CONNECTING WITH AND WAY=BILLING THROUGH VIA}

National, Western, Northern Pacific, Great Northern, Canadian, Dominion, Adirondack, Long Island, N. Y. \& Boston Dispatch, E. \& P., D. \& R. C. and all other Express Companies.

SPEC I A L OW RA TES on plants-20\% to 331/3\% less than regular merchandise rates apply to our shipIndiana, Columbus \& Eastern Traction Co. Springfield, Troy \& Piqua Railway Co.

\section{CONDITIONS OF SALE OF PLANTS}

We quote in this catalogue prices per dozen plants, per hundred plants, and per thousand. We will send three of a kind at dozen rates, twenty-five at one hundred rates, and two hundred and fifty ai thousand rates. Samples of any stock listed will be sent at the dozen rate. Special pains are taken to pack lightly, thereby reducing the expense of transportation to a minimum. Everything is labeled.

Articles offered in our retail catalogue. "Floral Gems," and not offered in this list, will be supplied at retail prices, less the following discounts: Vegetable and flower seeds in packets, bulbs and plants, 331/3 per cont.; fruits, 10 per cent. No disount on special offers or collections.

TERMS. Three per cent. discount for cash with order. Two per cent. discount on all bills paid within ten days.

REMITTANCES-Should be made by Draft, Postoffice Money Order or Registered fetter. Remittances in any other way are entirely at the sender's risk.

in the trade with whom they have had credit relations, otherwise cash must accompany drably.

Goods packed free of charge and in light corrugated paper boxes when weight of shipment will allow it.

Remember, it will not cost you any more to have your order sent in several shipmeits, provided each box weighs more than twenty pounds.

NEW. D.- Plants to be sent C. O. D. must have one-fourth of the amount with order. (and on account of a graduated scale of rates in some instances running to 25 and 30 pe cent.) from the regular merchandise rate at which plants have been expressed heretofore, and also that packages of less than 100 pounds are billcd at 100-pound rates. PLANTS BY MAIL-In a great many instances, orders which are to travel a long distance can be packed lightly and
PLAN sent by mail with a saving to the customer. If preferred in this way add one-fifth additiel

ance will be refunded. We would recommend when possible to have plants sent by express.
SHIPMENTS TO FAR POINTS-Shipments of Roses and some other plants to far points can be sent just as well with all soil removed and roots puddled, and at a great saving in expressage to customers. We will not remove all soil in any instances, however, unless requested All shipments being billed from here assure customers of the 20 per cent. reduction. However, if you have any fear
of it not being allowed, we will prepay shipments in such instances and add charges to pvoice.

PLANTS SENT BY FREIGHT are entirely at purchaser's risk. We will not be responsibe for any loss or damage.

Guarantee the guarantee all Plants, Bulbs and Seeds and to reach purchaser in good condition When forwarded by express (freight shipments at purchaser's risk), and hold ourselves in readiness to replace all stock that may accidentally prove untrue to label, free of charge, or refund the amount paid therefor; but it is mutually understood and agreed between the purchaser and
ourselves that our guarantee of genuineness shall not in any ourselves that our guarantee of genuineness shall not in any
case make us liable for a greater sum than that originally case make us liable for a greater sum than that originally received for such stock that may prove untrue. Most failures with Plants, Bulbs and seeds are due to soil conditions, unfavorable weather and other causes entirely beyond our control, rendering it impossible to guarantee success; and
although we will take all possible care to send only such stock as will under proper conditions give satisfactory results, we do not, and should not be expected to guarantee stock to grow or guarantce results in any way, and we cannot entertain complaints hat are not made promptly after receipt of goods.

\section{ERRORS AND COMPLAINTS}

We exercise the utmost can in filling orders, striving to do a little more than we prorise, yet in the press of business errors sometimes occur, ind when orders are received that are in any way damaged or not satisfactory, we wish to be promptly notified of the fact and will make such an to be promptly notified of th fact and will make such an adjustment of your claim as yll be satisfactory. When you write us simply give the natue of your complaint, giving a list of the plants damaged an/price paid for them and state whether you wish these item replaced or the amount re-
funded. It is nearly impossib to find time in the busy seafunded. It is nearly impossibe to find time in the busy season to adjust your complain promptly unless you give u
all the information required o do so in your first letter. 


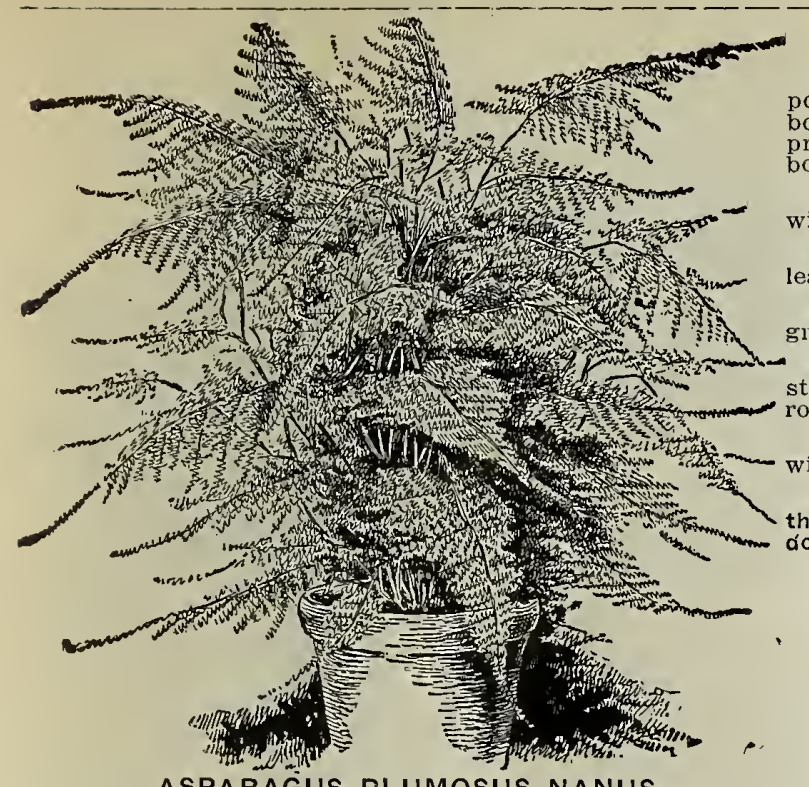

ASPARAGUS PLUMOSUS NANUS

One of the handsomest of our foliage plants. The leaves are of a bright. green, gracefully arched, and as finely woven as the finest silken mesh. It is one of the finest decorative vines recently introduced. By many florists it is used instead Pricmilax, as easily grown and very ruch $31 / 2-i n c h, 60$ cents per doz; $\$ 5.00$ per $100 ; 4$-inch, $\$ 1,00$ per doz.; $\$ 8.00$ per 100 .

\section{ASPARAGUS SPRENGERI}

Not only is it used for cutting in sprays for fine cut flower work, more particularly in connection with large Roses, etc. but grown in suspended pots it makes one of the prettiest decorative house plants we know of. The fronds are long and wiry, and for flat bouquets nothing equals it, for, while fleecy in appearance, in reality it is very stiff and forms an elcgant support for flowers. See illustration Price, $21 / z^{\text {-inch }}$ stock, 50 cents per dozen; $\$ 3,00$ per $100 ; \$ 25.00$ per 1,$000 ; 312^{-}$ inch, 60 cents per doz.; $\$ 5.00$ per 100 .

\section{HARDY AZALEA MOLLIS (For Forcing)}

Practically unknown for forcing purposes until a few years ago, the Azalea Mollis now holds a most important place, especially for the early winter months, and is gaining greater popularity each season; they are easily manipulated at a minimum of expense, and can readily be flowered any time after the middle of January. Fine bushy plants, fifteen to eighteen inches high, 15 to 20 buds, $3 \overline{5} \mathrm{c}$ each, $\$ 4,00$ per doz.

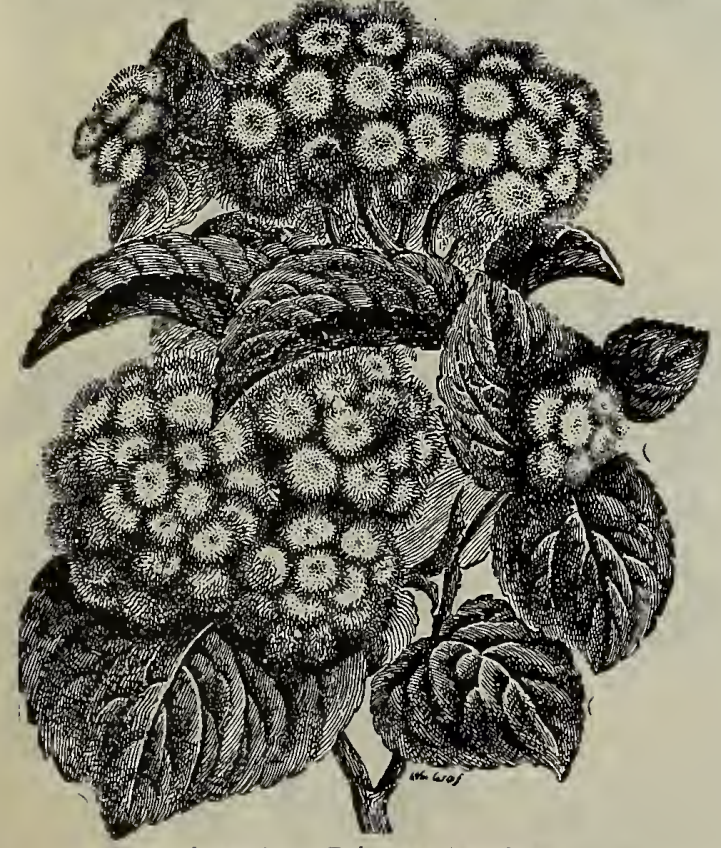

Ageratum Princess Pauline.

NOTE:-Our Asparagus Plumosus and Sprengerii are strong, healthy stock in good condition for ready sales.

\section{ACHYRANTHUS}

Indispensable for bedding purposes, either in massing or ribpreferable for massing or ribon lines.

GILSONII-Pointed leaf, green with yellow markings.

EMERSONII-Round b r o a d of a purplish-crimson,

McNALLY-Round broad leaf, Formosum-Color green streaked with yellow with narLINDENII-Color dark purple A nointed leaf

A good collection containing the above varieties, 40 cents per

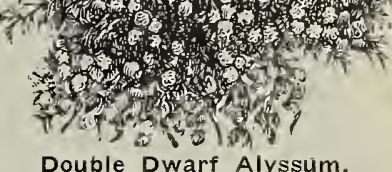

ALYSSUM

(Giant Flowered.)

DOUBLE WHITE-Has large double white flowers. Price, 40 cents per dozen; $\$ 3.00$ per $100 ; \$ 25.00$ per 1,000 .

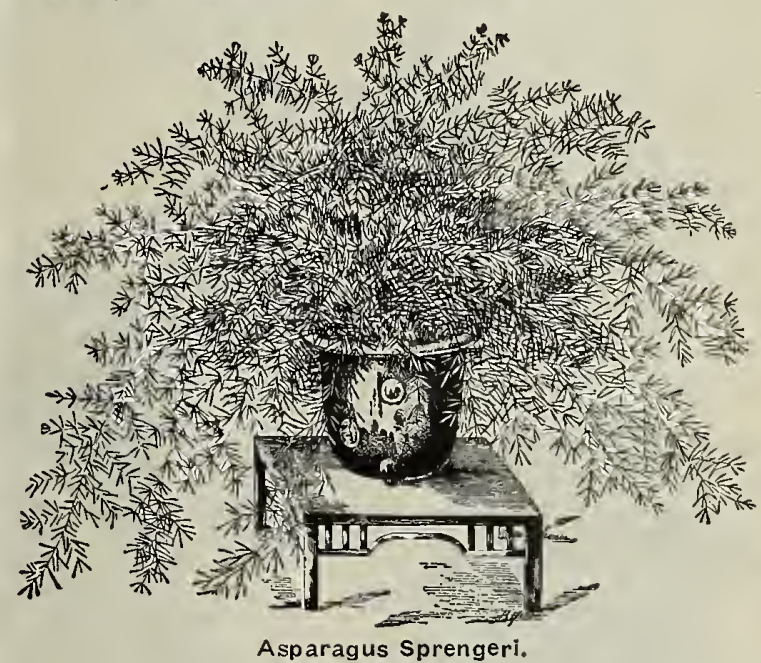

AGERATUMS

AGERATUM PRINCESS PAULINE

A most distinct and novel variety of dwarf, compact habit, its peculiarity being that both colors, blue and white, are
combined in the same flower. Price, $40 \mathrm{c}$ per doz.; $\$ 2,50$ per 100. AGERATUM STELLA GURNEY

It is undoubtedly the finest A geratum yet introduced. Coior a deep, even blue, and literally forming a sheet of bloom all summer. Dwarf and compact in growth. Price, 40 cents per dozen; $\$ 2.50$ per 100 .

\section{AGERATUM VARIEGATUM}

Beautiful variegated leaves. Price, 40 cents per dozen; $\$ 2.50$ per 100 . AGERATUM TAPIS BLUE A. fine dark blue variety and a fine bedder. Price, 40 cents per dozen; $\$ 2.50$ per 100

\section{AGERATUM DWARF WHITE}

Fine dwarf growing variety, always full of white blooms, a much more use-
ful variety than the old tall growing white, Price, 50 cents
per 100

\section{AGERATUM LITTLE \\ BLUE STAR}

A fine dwarf variety bearing olusters of small blue flowers. Price, 50 cents per dozen; $\$ 3.00$ per 100.

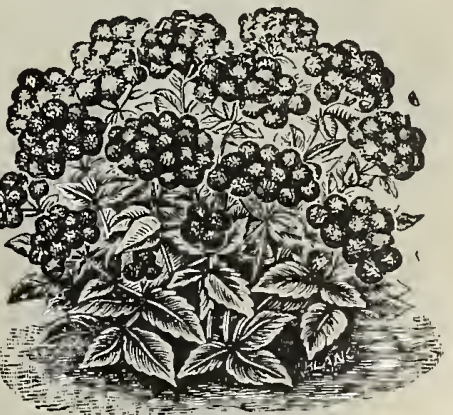

Ageratum Little Blue Star. 


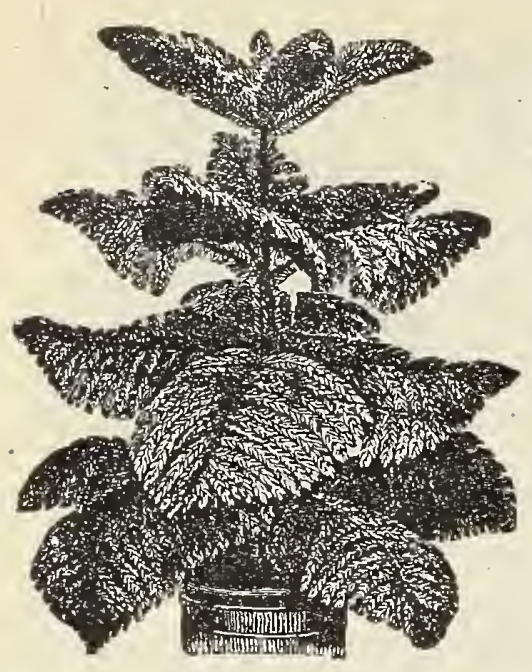

Araucaria Excelsa.

ABUTILON GOLDEN BELLS -(Golden Fleece.) A bright golden-yellow Abutilon of strong, vigorous habit and very free flowerriety on the market and combines large size. fine form-and depth of coloring.

ECLIPSE-Fine for baskets: and vases, trailing in habit. Its foliage is very attractive, beautifully marked dark green and yellow. son throat.

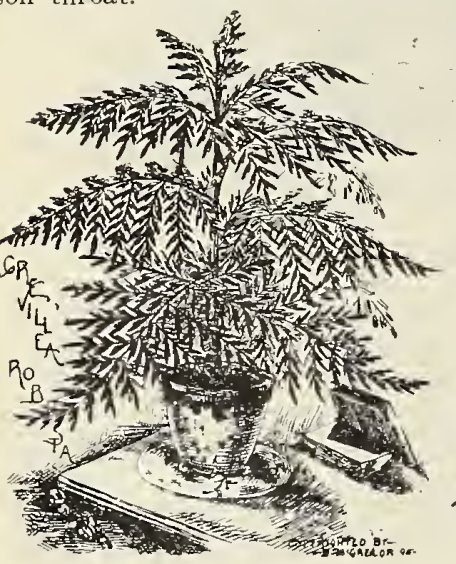

Australian silk Tree.

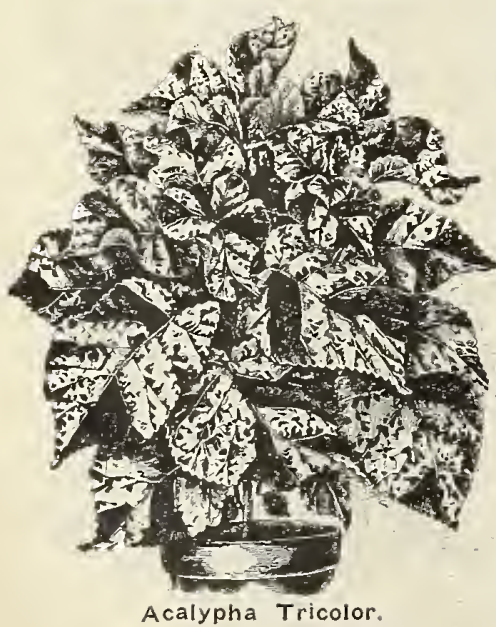

ABYSSINIAN BANANA

MUSA ENSETE-The noblest of all the foliage plants and the grandest of all the Bananas. The leaves are magnificent long, broad and massive, of a beautiful green with a crimson midrib. The plants grow luxuriantly, eight to ten feet. making it an exceptionally fine plant for the center of Canna beds, or, in fact, any place on the lawn. Price, strong 6-inch pot plants, $\$ 4.00$ per dozen; $31 / 2$ and 4 -inch pot plants, $\$ 2.50$ per dozen.

\section{ARAUCARIA EXCELSA} Norfolk. I sland Pine.)

Price, fine specimen plants, 15 to 20 inches high, three and four tiers of not less than four fronds each, 5 -inch pots, 75 each; $\$ 9.00$ per dozen.

ABUTILONS- "Chinese Bell Flower" Price, 50 cents per dczen; $\$ 3.00$ per 100 VESUVIUS-A strong, upright grower with large, green foliage, a free and concrimson.

THOMPSONII PLENA-Perfectly douile flowers that resemble in form a double Hollyhock. Color rich, deep orange, SOUV. DE BONNE-It is a strong, upright grower with large bright green foliage, distinctly edged, with a broad band of creamy-white and yellow. Color of flower bright orange-red.

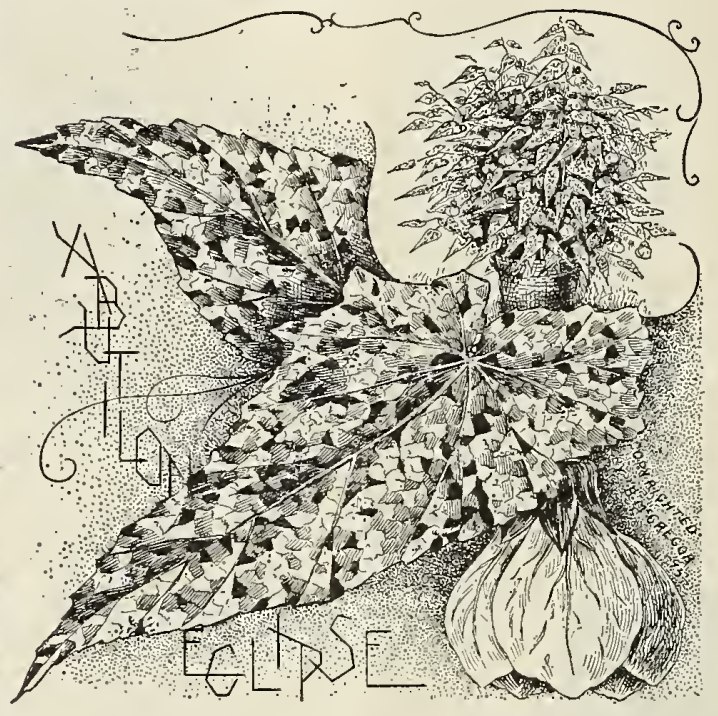

GREVILLEA ROBUSTA

A magnificent plant for deco rative purposes; of rapid, easy growth, fully valing $a$ rare Fern. T $h$ e young, growing light brown color, the tips bea coft down closely resembling raw silk, hence the name, "Silk Oak."

Price, 50 cents per dozen: $\$ 3.00$ per hundred.

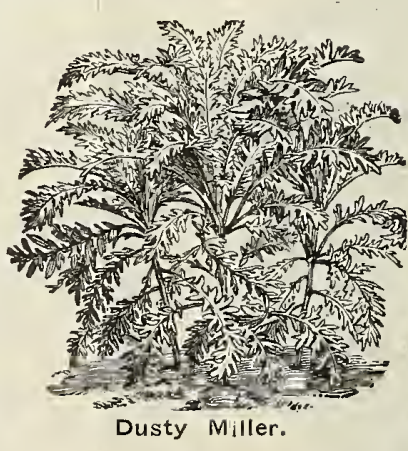

\section{DUSTY MILLER}

Centaurea Gymnocarpa.

Almost too well known for a description. This is the old Dusty Miller used for edging beds" of Coleus, Geraniums, Cannas, etc. Leaves silverywhite. Price, 40 cents per dozen; $\$ 2.00$ per hun dred; $\$ 18.00$ per thousand.

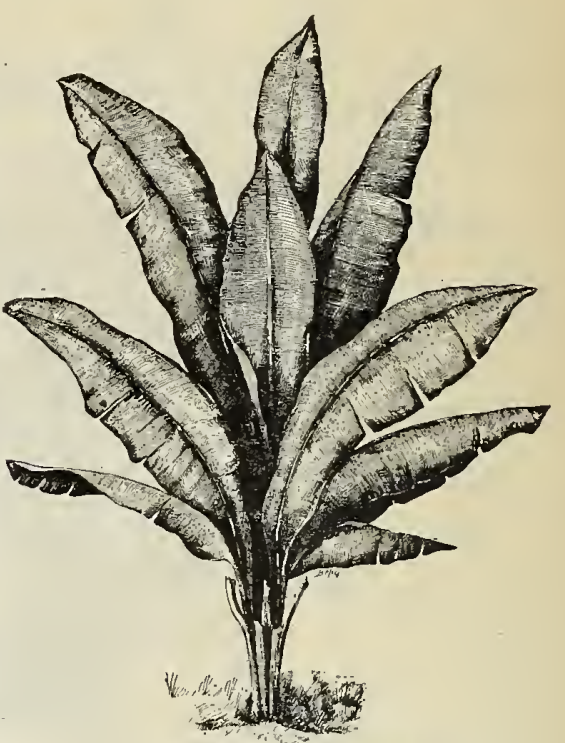

Abyssinian Banana.

ACHILLEA-THE PEARL See page 22 .

\section{AMPELOPSIS VEITCHII}

See page 21.

\section{ALOYSIA CITRIODORA}

(Lemon Verbena.)

Indispensable for the delightful fragrance of its leaves in the construction of bouquets, etc. Price,
40 cents per dozen; $\$ 3.00$ per 100.

\section{ACALYPHAS}

SANDERI-Dark green leaves, flower a long spike of crimsonscarlet. Price, 50 cents per dozen; $\$ 4.00$ per hundred.

MARGINATA-Foliage d a $\mathrm{rk}$ bronze, very showy. Price, 50 cents per dozen; $\$ 3.00$ per hun. dred.

TRICOLOR-Foliage bright red with crimson-bronze. Price 50 cents per dozen; $\$ 3.00$ per 100 .

BICOLOR COMPACTA-Leaves bright green margined with a wide band of lemon-yellow. Price, 50 cents per dozen; $\$ 3.00$ per 100 . 


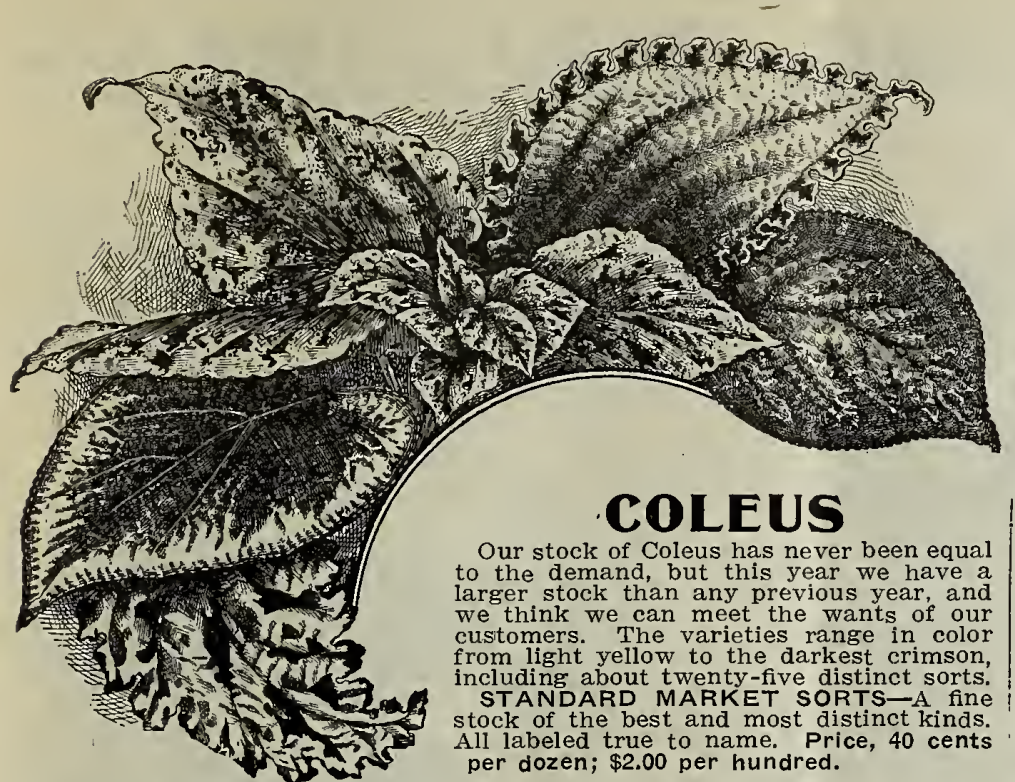

TUBEROSE (Large First Size Bulbs) DWARF EXCELSIOR PEARL-Grows about eighteen inches high, blooms very early, matures perfectly; flowers pure white, large size, per hundred; $\$ 8.00$ per thousand.

\section{GLADIOLUS}

MIXED-Our mixed Gladioli embrace a magnificent $v a r$ poorer "Groff." " Price, \$15.00 per 1,000; fine large bulbs.

\section{CALADIUMS}

CALADIUM ESCULENTUM (Elephant's Ears)-We have extra fine bulbs, which will start as soon as put in the ground. This is beds, in front of porches or massed in beds for lawn. Price, 7 to 9 inches in circumfer ence, 60 cents per dozen; $\$ 4.00$ per $100 ; 9$ to 11 inches in circumference, 85 cents per dozen $\$ 6.50$ per $100 ; 11$ inches and up, $\$ 1.25$ per dozen; $\$ 10.00$ per 100 .

\section{CYPERUS ALTERNIFOLIUS} (Umbrella Plant)

An ornamental grass throwing up stems about two feet high, surmounted at the top with a whorl of leaves, diverging horizontally, giving it a very curious appearance. Splendid for the center of vases or as a water
Price, 50 cents per dozen; $\$ 3.00$ per 100.

\section{CUPHEA TRICOLOR}

COLEUS ROOTED CUTTINGS

A choice assortment of the best kinds, put up in lots of not less than ten of one ver thousand.
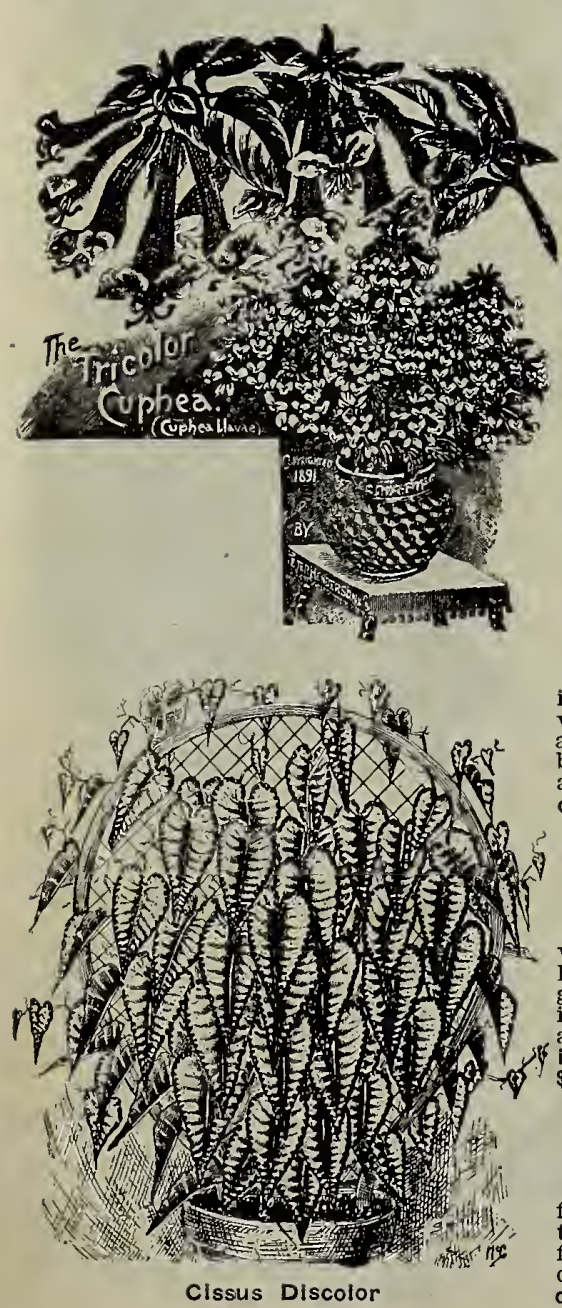

Flowers tubular in shape, one and one-half to two inches long, and have two bright scarlet wings at the end of each wings at the end of eacher, the tip of the
flower is bright purple,

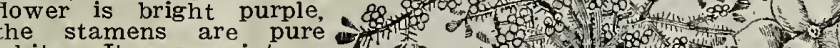
white. It grows into a bushy plant about fifteen inches high, and makes an elegant appearance for baskets or bedding. Price, 5 cents each; 40
cents per dozen; $\$ 3.00$ per hundred.

\section{CUPHEA} PLATYCENTRA

(Cigar Plant.)

A fine basket plant, with scarlet, pendulous flowers, neat, compact Price, 5 cents each: 40 cents per dozen; $\$ 3.00$ per hundred.

\section{EUPHORBIA SPLENDENS}

Crown of Thorns. A plant with thick, fleshy, twinng stems, which are covered with stout sharp spines nearly an inch long. The foliage is aright green and the flowers are cents per dozen; $\$ 4.00$ per 100 .

\section{CAREX JAPONICA \\ VARIEGATA}

An ornamental Japanese grass, which is extremely useful as a house plant. The blades with a center and white edge make and hanging baskets. Price, $21 / 2$. inch. pots 50 cents per dozen; $\$ 3.00$ per 100 .

\section{CISSUS DISCOLOR}

(Trailing Begonia.)

A climber with very beautiful oliage, deep velvety green, mottled with white on the upper surfaces, under side of a deep reddish-purple. Price, 50 cents per dozen; $\$ 4.00$ per hundred.
4.

, 100 \%

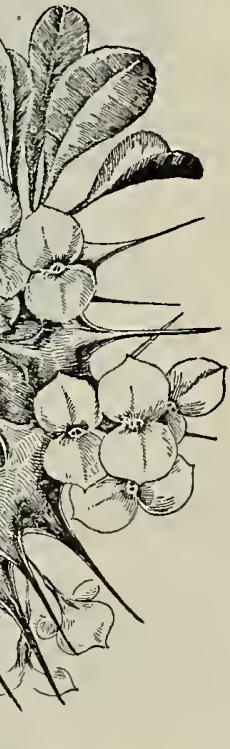
14 of o 


\section{FLOWERING}

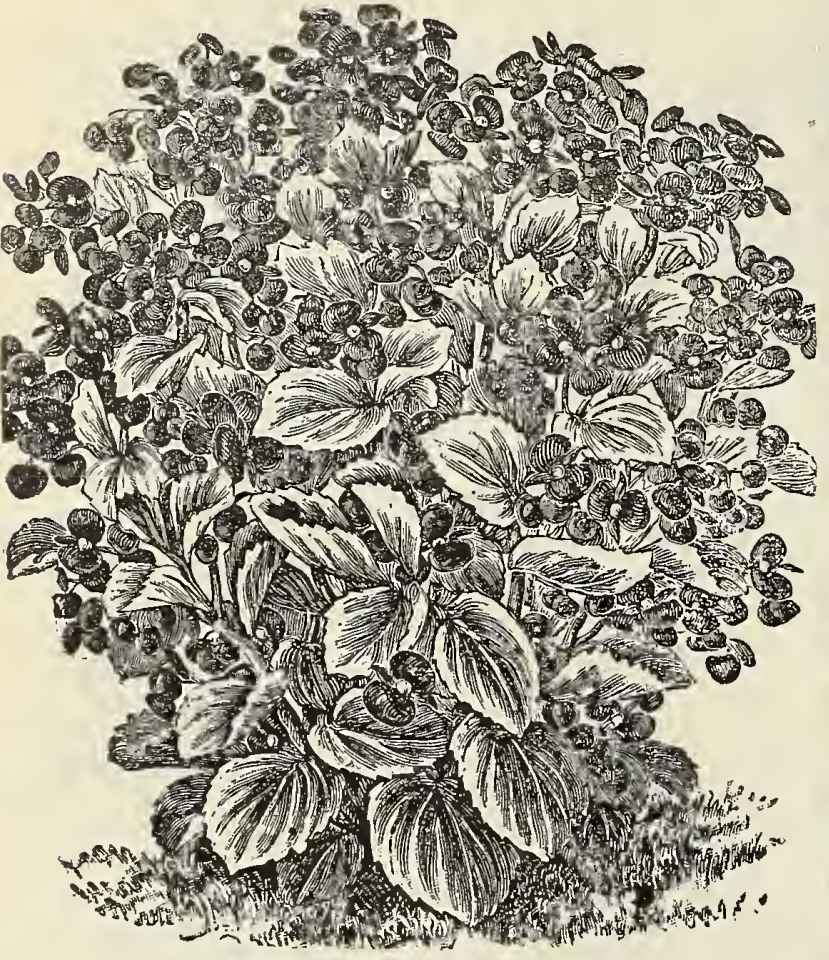

\section{BEGONIAS}

BEGONIA "GRACILIS LUMINOSA"

This beautiful Begonia is the best of the newer flowering Begonias. As the name implies, it is one of the most symmetrical and yet graceful Begonias we have ever grown. Its foilage resembles a little that grand old variety Vernon, rich glossy-green, often shaded deep bronze. It begins flowering during the summer months, and is a mass of bloom all through the winter. Flowers, when first opening, are bright cherry, changing to a clear coral-red. It thrives everywhere Price, 50 cents per dozen; $\$ 4.00$ per 100 .

\section{PRESIDENT CARNOT}

A beautiful variety, the bloom a most beautiful rosy-ver-
milion. The leaves milion. The leaves are of most beautiful form, a bronzegreen above the purplant assumes a fine tree form with a little attention. Price, 50 cents per

\section{BEGONIA}

SANGUINEA A showy variety, with very large side of which is a rich olive, the under side crimson, and of a peculiar leatherylike substance; like s ubsta n ce; rose to white. Price, 50 cents per dozen; $\$ 4.00$ per 100 .

\section{BEGONIA SPECULATA}

Leaves are in the form of a grape leaf. Color is a bright green with a background of chocolate; veins of a light pea-green, the whole leaf spotted with silver. Price, 50 cents per dozen; $\$ 3.50$ per 100

\section{BEGONIA THURSTONI}

This Begonia is a cross between B. Metallica and B. Saguinea, having the bright red foliage and veining underneath the leaves, and bright metallic green shading to red in the younger growth on top, with the deep veinings of the Metallica and smooth, glossy leaves and red stems of the Sanguinea; the flowers are a beautiful deep pink $\$ 4.00$ per 100 .

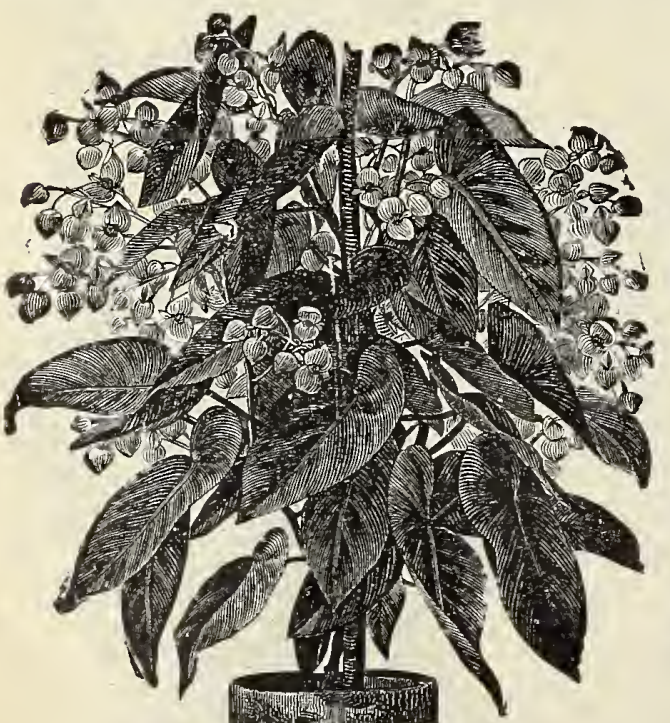

Begonla Rubra.

\section{BEGONIA ARGENTEA GUTTATA}

It has purple-bronze leaves, oblong in shape, with silver markings, and is in every way a most beautiful Begonia. It produces white flowers in bunches on ends of growth stems. Price, 50 cents per dozen; $\$ 3.00$ ner 100 .

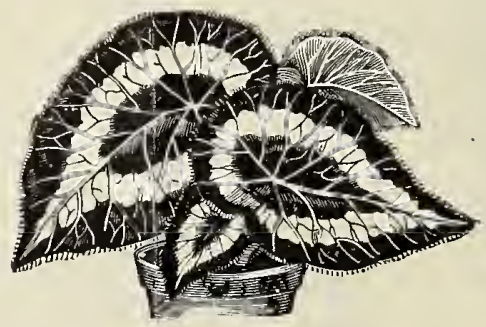

Rex Begonla

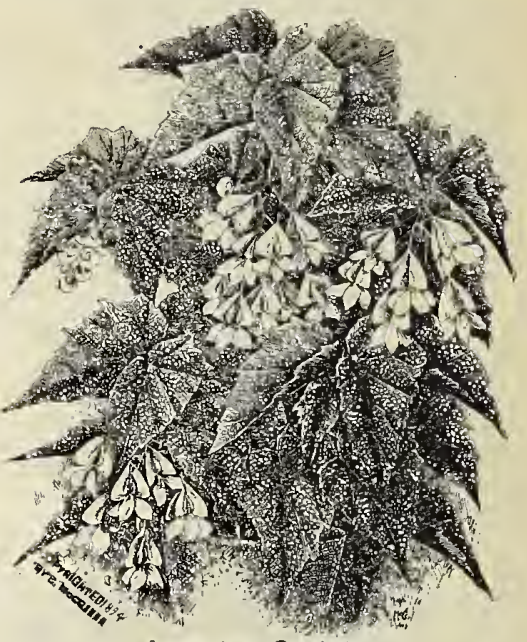

Argentea Guttata.

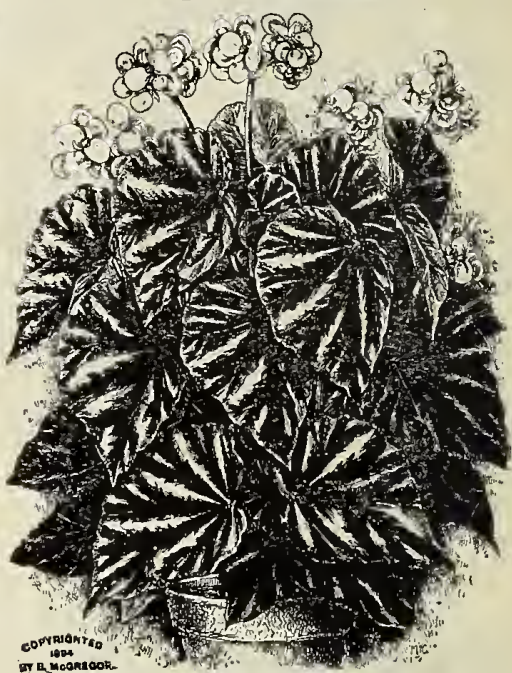

Begonia Thurstoni.

BEGONIA REX

We have a fine stock of Rex Begonias, our selection, in sis and eight varieties, 60 cents per dozen; $\$ 5.00$ per 100 . (Ready
April $1,1910$.

\section{BEGONIA RUBRA}

One of the finest Begonias in cultivation. Its darls glossygreen leaves, combined with its free-flowering habit, make it one of the very best plants for house or conservatory decoration. The flowers are a scarlet rose color. Price, 50 cents per 


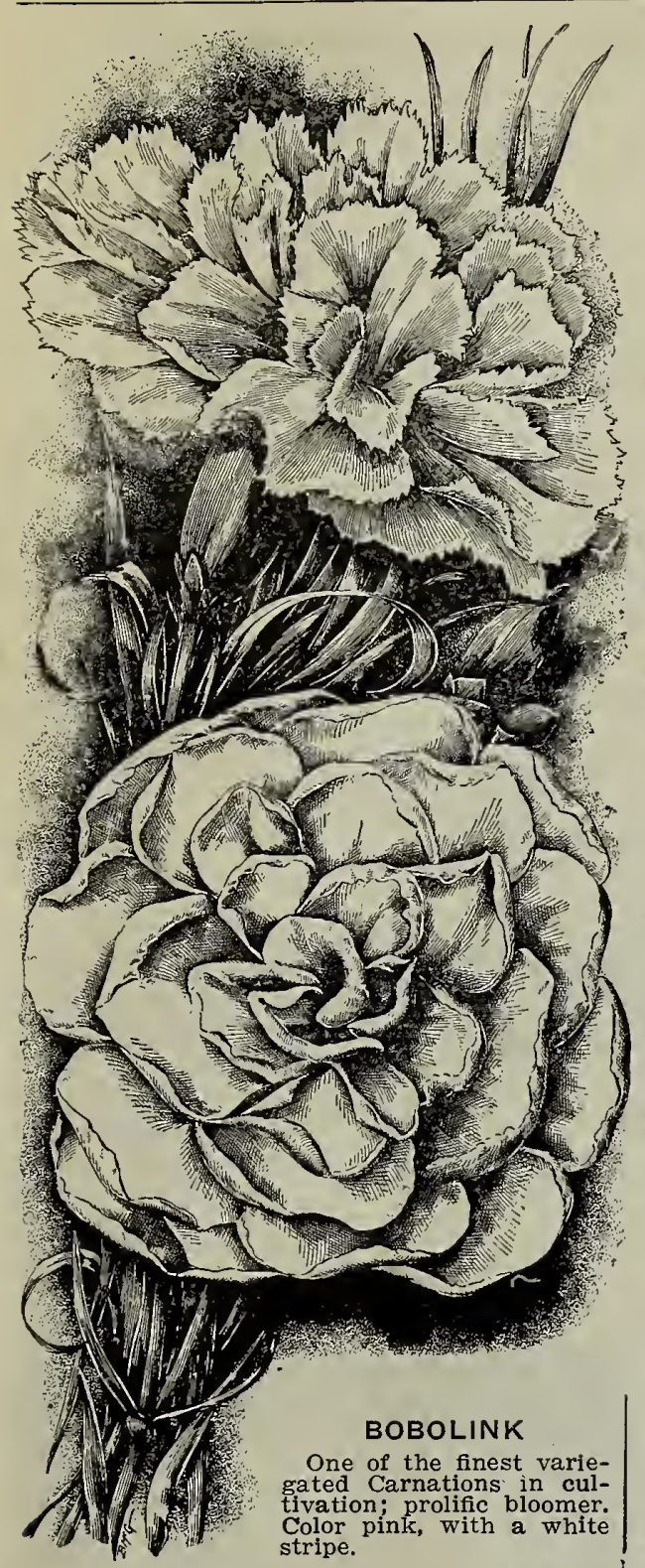

CARNATIONS

Strong, well established plants, $21 / 4$-inch pots.

50 cents per dozen; $\$ 3.00$ per 100 (except where noted).

\section{ENCHANTRESS}

A very pleasing shade of light pink, deepening towards the center. Very attractive and fine form; stem is strong and stiff; very healthy and of vigorous constitution.

The purest white sport from the variety Enchantress. ROSE PINK ENCHANTRESS

A rose-colored variety from the pink sort "Enchantress." It retains every good quality of its parent and will soon prove as popular. It is one of the most valuable commercial sorts.

\section{BEACON}

Fine scarlet variety, in front of the class of "reds." The color is brilliant and a variety of strong, sturdy growth; a very free blooming sort. Price, 50 cents per dozen; $\$ 3.50$ per 100 .

\section{LADY BOUNTIFUL}

The flowers are very large, borne on a stiff, strong stem; color a pure glistening white. One of the most fragrant Carnations we have.

\section{HARRY FENN}

This fine variety has become very popular. It makes a stiff, upright growth; a large flower; color bright crimson.

\section{WHITE PERFECTION}

All that its name implies. Bloom is abundant, of large size and immaculate whiteness.

Deep pink; extra long steCRAT Deep pink; extra long stems and large flowers. A strikingly handsome
and very valuable new sort. Price, 50 cents per dozen; $\$ 3.50$ per hundred. VICTORY A brilliant scarlet; one of the largest-flowering varieties we have
listed. The best commercial scarlet to date. Price, 50 cents per dozen; $\$ 3.50$ per 100

\section{WINDSOR}

A grand new variety; color pure medium pink; form, size and growth of the best. Price, 50 cents per dozen; $\$ 3.50$ per hundred.

\section{HARLOWARDEN}

A bright crimson. The stem is long and stiff; a strong grower. ELDORADO

Light, clear yellow, petals edged with a narrow band of light pink. A strong, vigorous grower with fine healthy foliage, stems of good length, supporting large, finely formed flowers

\section{BOSTON MARKET}

A very free blooming Carnation. It is a strong grower, with very large white flowers.

A pure scarlet; flowers very full reds cultivated, because it blooms early and gives a good supply of flowers. PROSPERITY

A variegated variety of a type unlike any of the striped sorts. The white and pink are about evenly divided. A large flower, of good form, fragrant, and a splendid keeper.

\section{QUEEN LOUISE}

Flowers pure white, fragrant and large. Center well flled, rounding the flower to a most pleasing form.

MADAME JOOST

Color a very delicate pink. A rine grower, producing a long stem and good foliage. A good commercial variety.

\section{H. CRANE}

Color a flaming scarlet; growth strong, hardy; broad foliage, and Queen Alexandra makes a well-formed plant.

\section{SUNBEAM}

Strong grower and free flowering, long, strong stem; flowers three inches in diameter and a deep golden-yellow with faint red stripes.

HARDY PINKS IN GOOD VARIETY LISTED ON PAGE 22

\section{LARGE FLOWERING DAISIES \\ MARGUERITES}

Very profitable for cut flowers. Always in demand and so easily handled. Price, 40 cents per dozen; $\$ 2.50$ per hundred.

WHITE-(Mme. Gailbert.) Best white, having a ray of white petals around a salmon disc. Splendid for cut flowers

YELLOW-(Etoile d'Or.) Finest yellow, large flowers and deep color.

BLUE-(Agathea Celestes.) The flowers are daisy-shaped, of a delicate light blue, with a yellow disc. It blooms in great profusion. Price, 50 cents per dozen; $\$ 3.00$ per hundred.

\section{Double-Flowering Marguerite.} "QUEEN ALEXANDRA"

The new Anemone-flowered Marguerite or Paris Dalsy-The flowers are from two and one-half to three inches in diameter, and of a pure white color, the greatest percentage of these coming full double.

Price, 50 cents per dozen; $\$ 3.00$ per hundred.

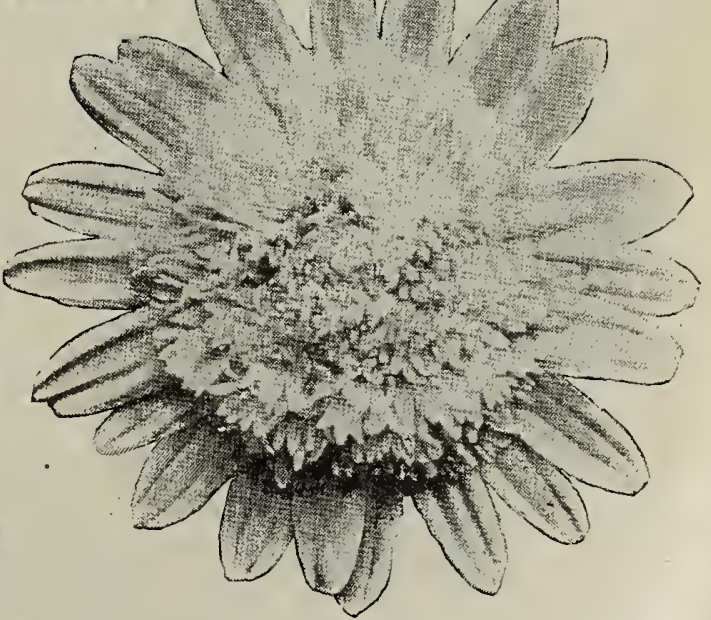




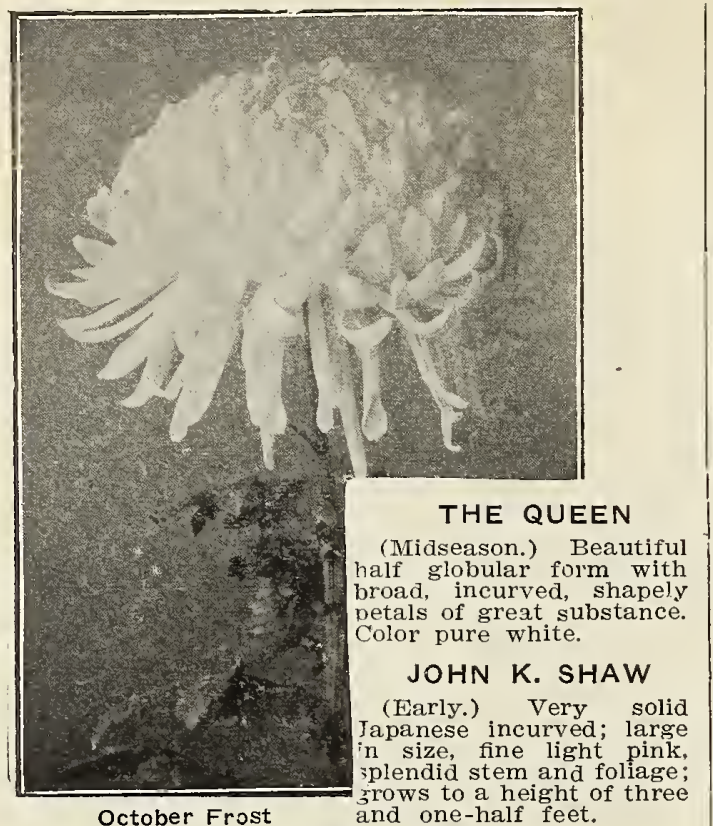

WHITE BONAFFON

(Late.) One of the most useful of the white varieties. Color pure white, splendid form; one of the best; three feet. MINNIE WANAMAKER

(Late.) Pure snow-white, incurved and perfectly double, with a breadth of petal and grandeur of build that is only

\section{MONROVIA}

(Early.) Color deep orange-yellow, with incurved petals. A good early cut flower variety.

GEORGE S. KALB

Magnificent white, large globular flowers, early, free bloomer.

\section{OCTOBER SUNSHINE}

(Early) This fine variety eclipses all other early flowering golden-yellows; the petals are incurved.

\section{DR. ENGUEHARD}

One of the leading pink varieties. Color a deep, clear pink, much darker shade than any other listed. Inicurved, with 作 An exceedingly strong grower.

\section{CLEMENTINE TOUSET}

(Early.) A large, early white, characterized as the early Chadwick. Splendid stem and foliage; very easy doer. Color glistening white, sometimes tinted pearl.

\section{ESTELLE}

(Early.) Produces extra sized flowers of the purest white; fine deep orm, with foliage evenly distributed along stem. Marketable bloom were cut on October 4th, and under the same conditions of culture it came a week earlier than its parent, "Glory of the Pacific," with a far superior flower in shape and substance.

\section{LAVENDER QUEEN}

(Midseason.) An immense solid flower, very full and compact, outer petals reflexed, center petals erect, forming a flower of great depth. It is a lovely color, soft silvery lavender-pink, decidedly distinet from any other pink. Of good growth, medium height, stiff stem and good foliage.

$$
\text { OPAH }
$$

(Early.) The color is pure white from crown; and ends of the petals a ( It resembles in form Yellow Fitrigioram, having reflexed petals which make almost a perfect ball.

\section{NELLIE POCKET}

(Midseason.) This grand Chrysanthemum is a beautiful white variety of mammoth size, and of the most artistic form and finish. Flower is reamy-white, with long drooping florets curling to the tips, making a creamy-whict bloom of the most graceful and lovely form.

\section{IVORY}

(Early.) Unexcelled for pot eulture or cutting; pure white flower of exquisite form and finish.

\section{NIVEUS}

(Midseason.) A splendid snow-white variety. Center irregularly incurving with outer petals reflexing nearly to the stem. Constitution robust, foliage large and abundant

\section{MRS. O. P. BASSETT}

It is a sport from the grand variety Mrs. Henry Robinson, and takes after its parent in all the fine qualities. The color is a fine canary-yellow of a soft texture.

\section{GLORY OF THE PACIFIC}

It is of magnificent size and depth, with broad petals which finally reflex, showing the clear pink color to excellent advantage.

SPECIAL NOTE:-Our stock of Chrysanthemums this season is excellent.

\section{CHRYSANTHEMUMS}

called the "Queen of Autumn," is the most gorgeous all the Fall and Winter blooming plants. The

\section{MARIE LIGER}

velvety finish, fine stem and foliage. 列 larg'e size. The GOLDEN GLOW

MRS. COOMBES

fine very early pink variety of the larg. An extra fint after Glory of the Pacific and Ivory. Color beautiful rose-pink. resembling viviand lso in style, but the petals are broader. ROBT. HALLIDAY

arly.) Is still near the top of the list of early yellows; it to show its possibilities, but this va-

(Early.) An exceptionally fine variety for exhibition pur-

OCTOBER FROST

A pure white, with broad, slightly incurved petals. Strong grower, with heavy foliage, and one of the earliest MME. F. BERGMANN

white, with creamy center; a strong, sturdy The most popular white variety with flo-

\section{BEATRICE MAY} (Early.) This is a fine cut-flower variety, grown very ex-
tensively by all the leading florists. A beautiful incurved apanese variety; color white, flushed with pink. This beauluable addition to the early flowering

\section{WM. DUCKHAM}

Color a deep, clear pink. Incurved with a broad petal. The flower is very large, measuring nine inches in diameter and supported by a long stiff stem with good foliage. An exceedingly strong grower and comes in flower

\section{ALICE BYRON}

This is a magnificent variety with every forets. In some stages it resembles Mrs. H. Weeks, but as the florets expand, the whole fall back and form into a deep,

\section{MERRY CHRISTMAS}

sensational novelty of the year. A late flowering, globurved variety of perfect form and growth. white.

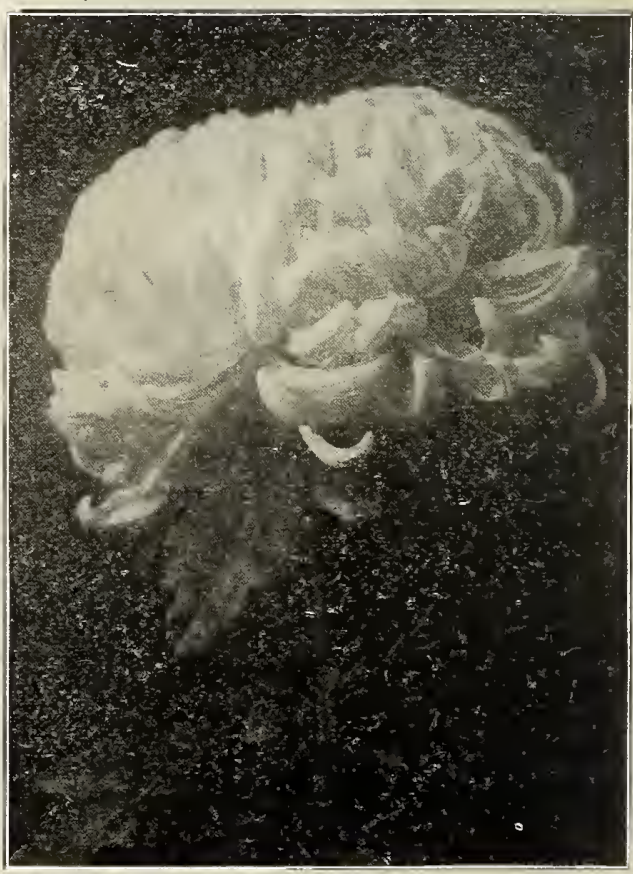

Clementine Touset.

All clean, heatthy slock. Write for prices in large quanlities. 


\section{CHRYSANTHEMUMS-Continued.}

Price, 50 cents per dózen; $\$ 3.00$ per $100 ; \$ 25.00$ per 1,000 . MISS CLAY FRICK

This is a white sport from the grand prize-winning variety, Wm. Duckham. The flowers are incurved with bright petals, very large and held up by strong stems with good foliage.

\section{NAGOYA}

One of the largest and finest brilliant yellows. Large petals, very long; variety of good growth, splendid stem and good habit.

\section{ROSAIRE}

A mammoth-flowering variety resembling the novelty Pacific. Supreme in foliage, but has larger petals. Color a beautiful shade of pink, intermediate between Pacific and Wm. Duckham Very heavy in substance; flowers borne on long, stiff stems, and well formed.

\section{GOLDEN WEDDING}

(Late.) This is undoubtedly the grandest golden-yellow variety ever introduced. Nothing can exceed the richness of its color it is unrivaled in this respect. It is a remarkably vigorous growe and has such strength of stem that it carries its great globular flowers erect, giving it a bold, majestic appearance.

\section{TIMOTHY EATON}

(Late) It is an enormous globular Japanese incurved variety of perfect form and growth. Color a pure white, even whiter than its parent, Mínnie Wanamaker.

\section{COL. D. APPLETON}

(Mídseason.) Flower is a magnificent Japanese incurved with lower petals reflexed and not showing any center. Besides the immense size and beautiful shade of clear yellow, another point in its favor is its almost faultless stem and foliage, growing fully up to the flower.

\section{YELLOW EATON}

(Late.) Color soft chrome broadpetaled, incurving Japanese type, showing no center, very large; tíficate at Indianapolis

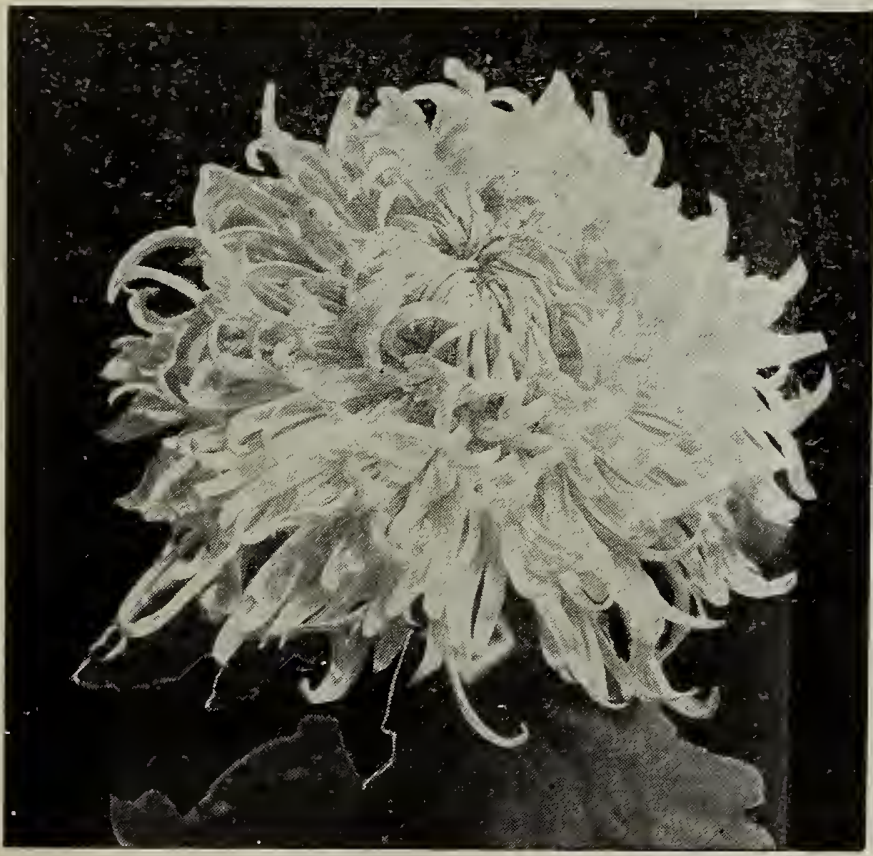

Effie Dean, or White Maud Dean

\section{WHITE MAUD DEAN}

A beautiful sport from the fine commercial sort, Maud Dean The color is a charming ivory-white, beautifully veined, when flower is fully developed shows the carmine center, making it very effective.

\section{MAUD DEAN}

An immense pink variety finely incurved petals broadly shell-shaped. One of the largest flowers exhibited in the fall shows. Almost a pure selfpink.

GOLDEN EAGLE

(Late.) It is almost of globular form. The outer petals are a delicate lavender, forming a decided band of color; the inner petals are clearly lemon, of tentimes flowers come a pure white

\section{MRS. JEROME JONES}

A new variety which will prove one of the most valuable yellow Chrysanthemums ever introduced. It will prove as great a favorite as the grand yellow Major Bonaffon. The color is a deep yellow, flower of compact, incurved form, with a strong stem holding the flower quite erect.

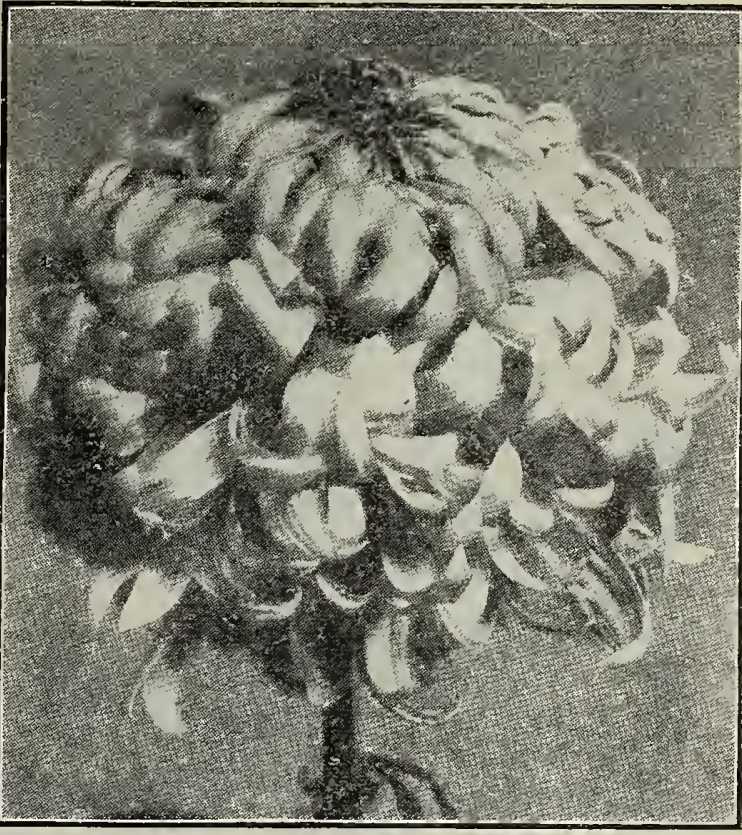

Yellow Jones (Mrs. Geo. F. Baer)

MRS. GEO. F. BAER

(Late.) The yellow sport from Mrs. Jerome Jones. The color is good, and it fully equals its parent in all other essential points, an easy grower, medium height and good foliage.

\section{R. E. RICHARDSON}

(Late.) The brightest clearest pink yet introduced in the Chrysanthemum family. Both color and form are exquisite. Center petals incurved and outer ones reflexed. Comes in flower about November 20th, making it a fine Thanksgiving variety. Good stem and foliage

\section{LORD HOFETOUN}

A very handsome flower of the richest scarlet-crimson, with shining gold reverse; when fully expanded the center petals show the gold, while the outer petals MAJOR BONAFFON

(Late.) Soft clear yellow, full to the center, eight inches in diameter and nearly as deep. In perfect form and hnish, habit dwarf, keeping qualities excellent. It is entirely distinct in color and form from Eugene
Dailledouze..

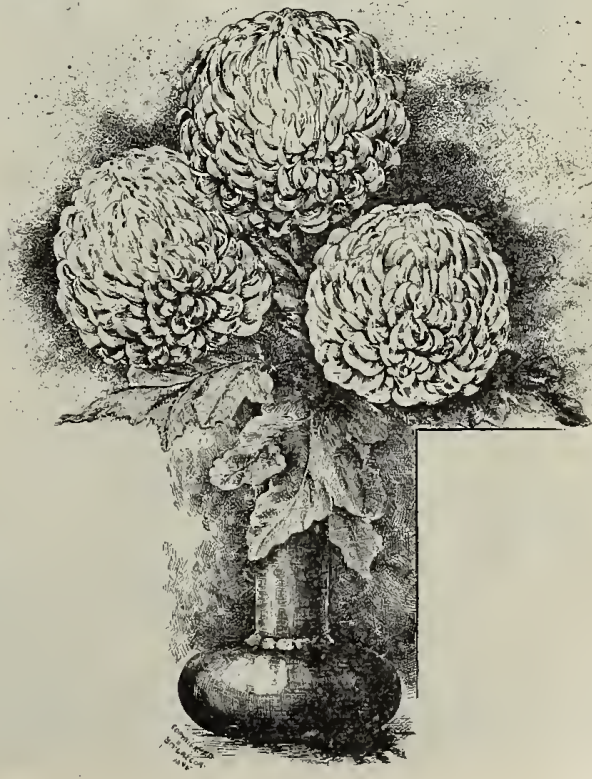




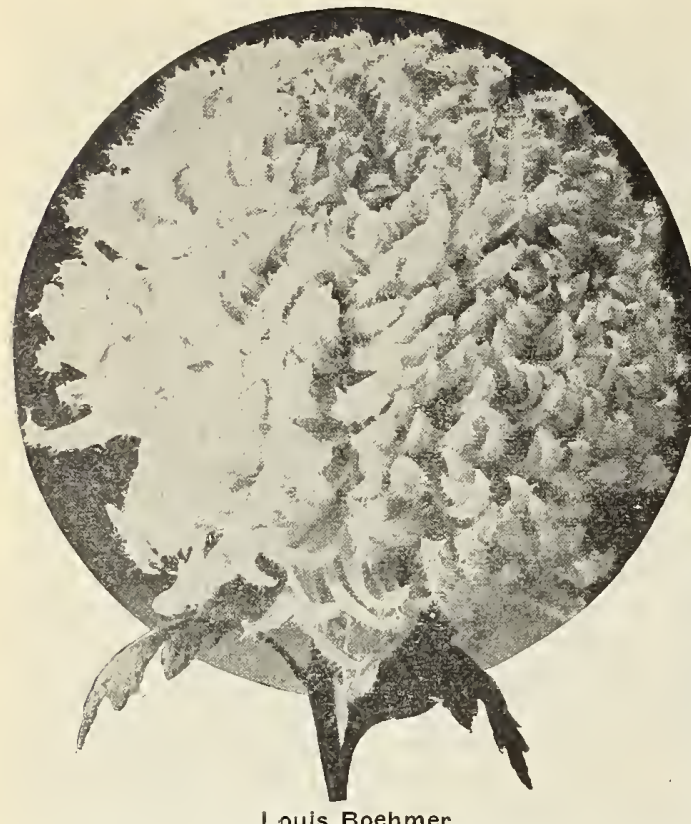

Louis Boehmer

\section{OSTRICH PLUME CHRYSANTHEMUMS}

\section{Price, 50 cents per dozen; $\$ 3.00$ per 100 .}

Mrs. Higginbotham-Enormous bright pink, broad spreading Japanese variety; with extremely wide cupping and incurving petals which are covered with glandular hairs.

Perle of Lyonaise-Bright, clear golden-yellow, somewhat plumed, quite full, one of the very finest: of medium size, beautiful globular form; L'Enfant Des Deux
Mondes-Pure white. Like the parent, it is a strong grower of good habit, and

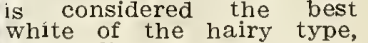
white of the hairy type, inent place in any set of this peculiar st

Louis Boehmer-(P i n k Ostrich Plume)-"Lou is Boehmer" has the same wonderful hair-like growth or excrescence that appeared for the first time in the white variety, "Mrs. differs from it in color having a most beautifu caving a most beautifu shaded with silvery-pink on the ends of the petals. Wm. Falconer-A soft delicate blush, shading almost to white.

\section{Large Flowering and Hardy Pompone fasHIONED HARDY}

\section{CHR Y SANTHEMUMS}

Price, 50 cents per dozen; $\$ 3.00$ per $100 ; \$ 25.00$ per 1,000 . This class, which produces a mass of small blooms and of all the colors of the
Chrysanthemum family, are delightful in the extreme. They are used in beauChrysanthemum family, are delightful in the extreme. They are used in beauplace and they have the added value of being hardy. By disbudding, nice flowers can be had two or three times the natural size.

Arctic-Strong robust color, flowers in immense clusters, snow-white.

Homestead-Strong shade of delicate pink.

Fred Peil--A beautiful bright scarlet. "One of the best."

Victory -A beautiful large flower, hardy and white.

Rose-Crimson-A very striking variety, color beautiful crimson suffused with rose-pink.

Rhoda-Flowers borne in large clusters, color pink showing white in center Autumn Glow-This is quite a novelty and early blooming variety; they are double, color coppery-bronze with a tinge of red on outer petals.

Tennyson-One of the best of the hardy family; color beautiful golden-yellow.

SPECIAL NOTICE - WRITE FOR SPECIAL PICES IF YOU ARE IN THE

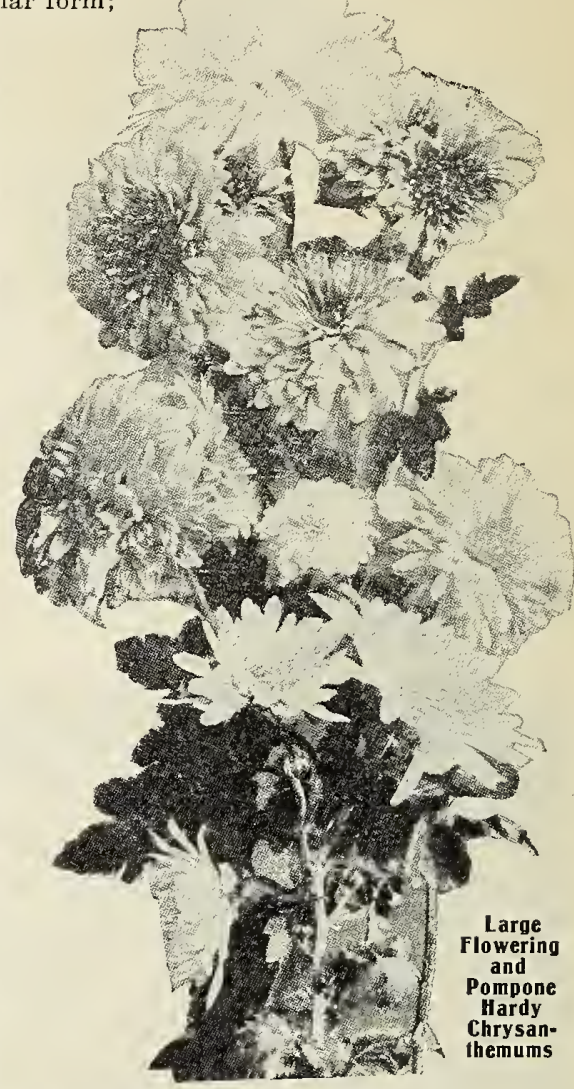

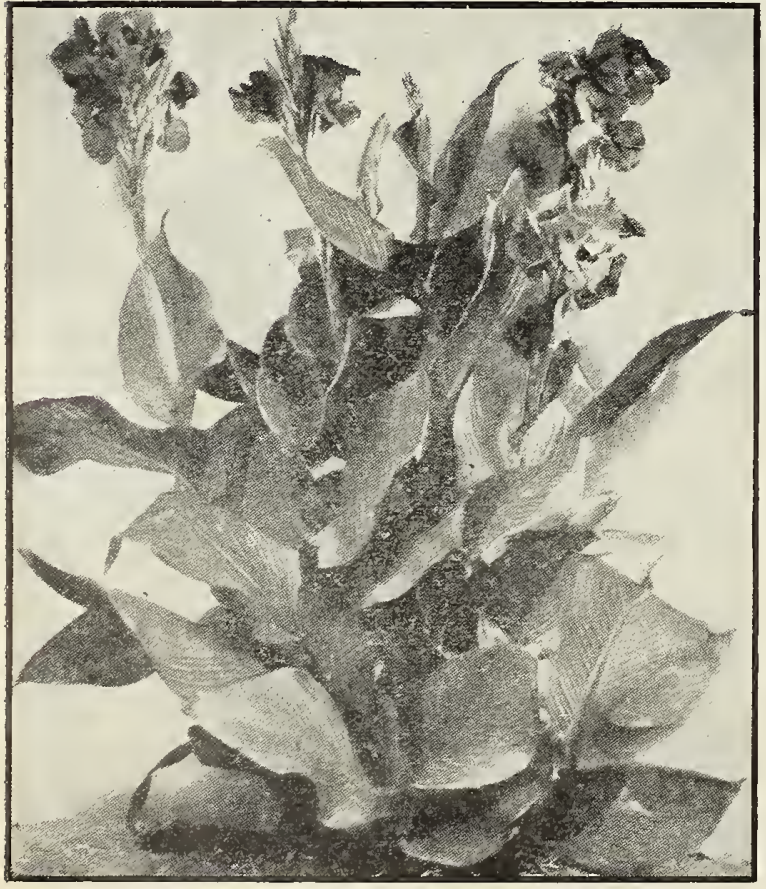

King Humbert (Bronze)

\section{CANNAS}

Strong plants from pots, 50 cents per dozen, $\$ 4.00$ per 100 (except where noted.)

\section{BRONZE LEAVED}

King Humbert-(Bronze Leaf, 4 to $4 \frac{1}{2}$ feet.) Flowers are as large as those of any of the Orchid-Flowered Cannas, yet have the firmness and substance of the Crozy type. Bright orangescarlet, streaked with crimson. Price, $\$ 1.00$ per dozen; $\$ 8.00$ per hundred.

Shenandoah-(4-5 feet) The plant grows to a medium height, having broad chocolate-colored foliare with a bronze-metallic lustre. The flower is large and of a pretty shade of pink, making a pretty contrast with the bronze foliage. Price, 50 cents per dozen; $\$ 3.00$ per 100 .

America-(4 feet.) The first red-leaved Canna in the giant flowered class. Height four to five feet. Foliage fine glossybronze, almost as if varnished. Flowers extra large, deep orangeflamed and striped with deeper shade.

Etna-(Bronze, 3 feet) Flowers of bright vermilion-scarlet mottled with deep red.

Egandale-(Bronze, 4 feet.) A good darlk-leaved variety. The foliage is good, habit sturdy. Flowers a currant-red of a good size.

Canna Gigantea, or Robusta-Beautiful bronzy foliage, immense eaves, the largest and tallest of all Cannas. Flowers red; excellent for centers of beds and background for other planting.

Wm. Sanders-A strong growing Bronze Canna (41/2 feet). One f the best of recent introduction, scarlet flower. Price, $\$ 1.00$ per dozen; $\$ 8.00$ per 100 .

These Cannas are all strong potted plants from $2 \frac{1}{2}$ and 3 -inch pots, all in good condition for immediate effect. 

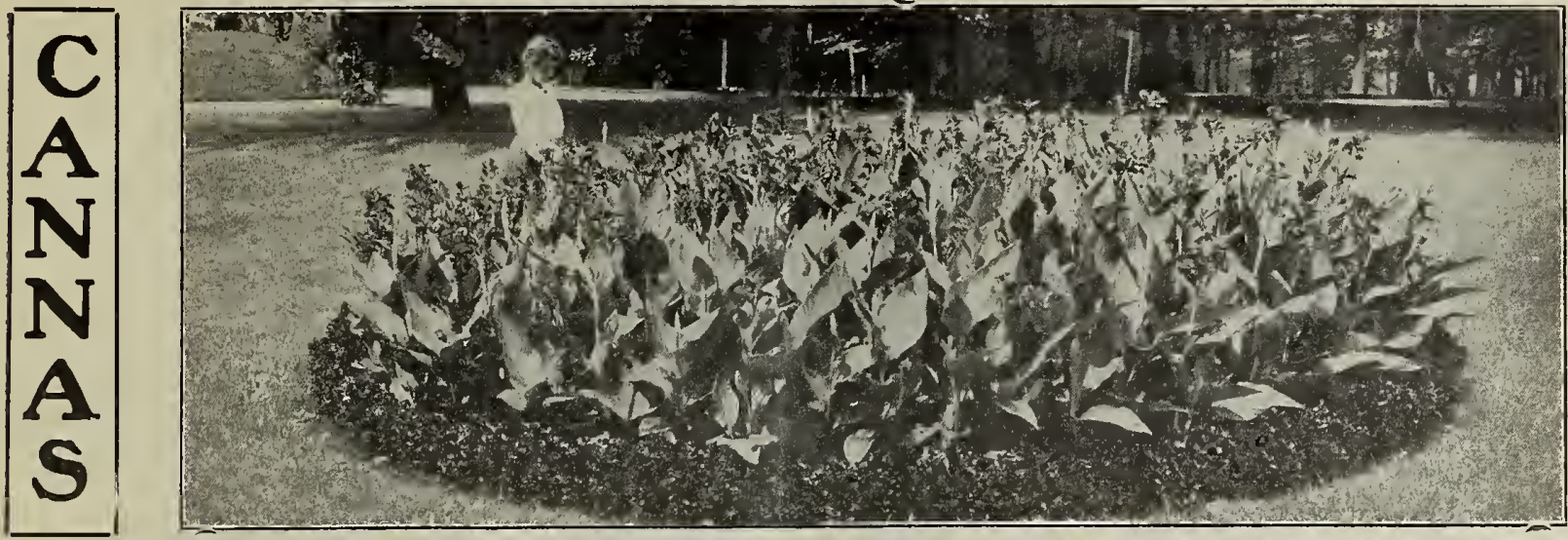

All Cannas listed below are strong well established potted plants,

Price, 50 cents per doz.; $\$ 4.00$ per 100 (except where noted). J. D. EISLE-(Height, 4 feet.) This fine new Canna is an improved Charles Henderson. Flowers a flaming scarlet in (3 constant and abundant bloomer. spotted with bright red. A strong, robust grower and flowers

MLLE. BERAT- $(31 / 2$ feet. $)$ It is much the darkest of all pink Cannas, being dark carmine-red. A showy, effective bedder. Price, 50 cents per dozen; $\$ 3.00$ per hundred.

ALEMANNIA-(5 feet.) An immense flower, orange, with bright yellow border spotted with orange. Distinct. Price, 50 cents per dozen, $\$ 3.00$ per hundred.

AUSTRIA-(5 feet.) Orchid flower of a golden-yellow color. Strong grower. Price, 50 cents per dozen; $\$ 3.00$ per hundred. BURBANK- (2 to 3 feet.) An Orchid flowering Canna, very similar to Austria, only a little dwarfer in habit; color clear golden-yellow. Price, 50 cents per dozen; $\$ 3.00$ per hundred.

CHAS. HENDERSON-(3 feet.) Height two and one-half to three feet; color brilliant deep crimson; broad deep green foliage, narrowly margined with bronze. Price, 50 cents per dozen: $\$ 3.00$ per hundred.

BLACK PRINCE-(4 feet.) Large flowers of a vivid crimson color. It has a very compact, bushy growth about four feet in height. CHABANNE-(4 feet.) Clear orange-scarlet. Price, 50 cents per dozen; $\$ 3.00$ per hundred. ELDORADO- 4 feet.) Color is a rich, pure golden-yellow speckled with a red.

MARTHA WASHINGTON-(3 feet. ) Color is a pure pink, a little lighter than Mlle. Berat.

SOUV. D'ANTOINE CROZY-(4 feet.) A Canna we can recommend as one of the best we have today. Its color is an intense scarlet, bordered with a band of deep goldenyellow.

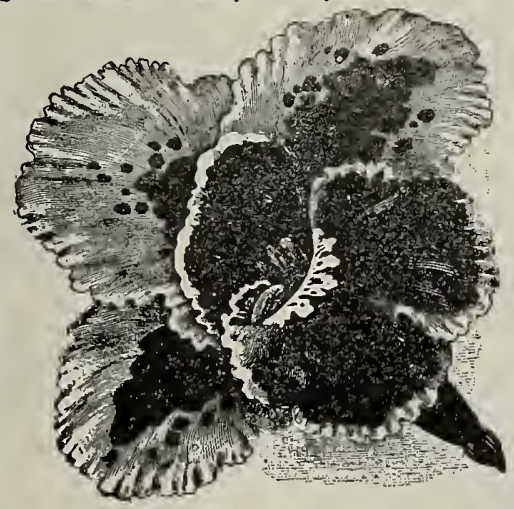

Canna Mme. Crozy
LOU ISI A N A(Height $3 \frac{1}{2}$ to 4 feet.) It is a vigorous grower. Flowers like beautiful orchids; size, often more than seven inches across and every inch a vivid scarlet.

MADAME CROZY -(3 to 4 feet.) The color is a brilliant vermilion-s c a r le t bordered with deep golden-yellow; $\mathrm{th}$ e flowers are borne in great clusters, and in such profusion plant with a blaze of glowing color.

QUEEN CHARLOTTE-(21/2-3 feet.) The shape and markings of the flowers are very large, with broad, rounded petals, slightly recurved. A bright orange-scarlet, deeply edged with bright canary-yellow.

CRIMSON BEDDER-One of the most showy and longest lasting flowers. Brightest imaginable shade of crimson-scarlet; compact in growth. Flowers remain in perfect condition for a longer period than ordinary varieties; valuable for planting in masses where bright red color is desired.

THE CRIMSON CANNA, DUKE OF MARLBOROUGH( 3 to $31 / 2$ feet.) The darkest fiowered Canna in existence;
deep crimson-maroon; four feet.

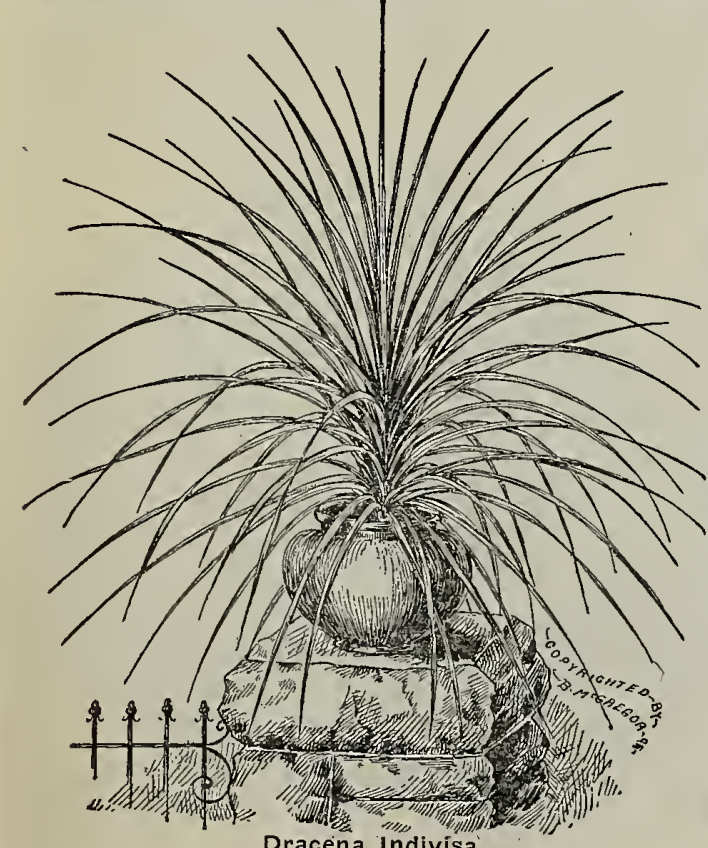

DRACENA INDIVISA

Of all the plants in use for centers of vases, baskets, or beds in the open ground, nothing is so val uable as this is. Price, 50 cents $_{S}$ per dozen; $\$ 3.00$ per hundred; strong 4-inch stock, 90 cents per dozen; $\$ 7.00$ per 100

\section{FICUS, or}

RUBBER PLANT

Again this year we have to offer a fine lot of Rubber Plants. They are now in four and five-inch pots, and all from top cutting, and well leaved from pot up. Price, five-inch pots, ten to fourteen inches high, $\$ 3.00$ per dozen; $\$ 25.00$ per hundred.

SPECIAL NOTICE

We have never had a finer lot of Ficus, all perfect plants, and healthy stock. Something you should find a Dracena Indivisa

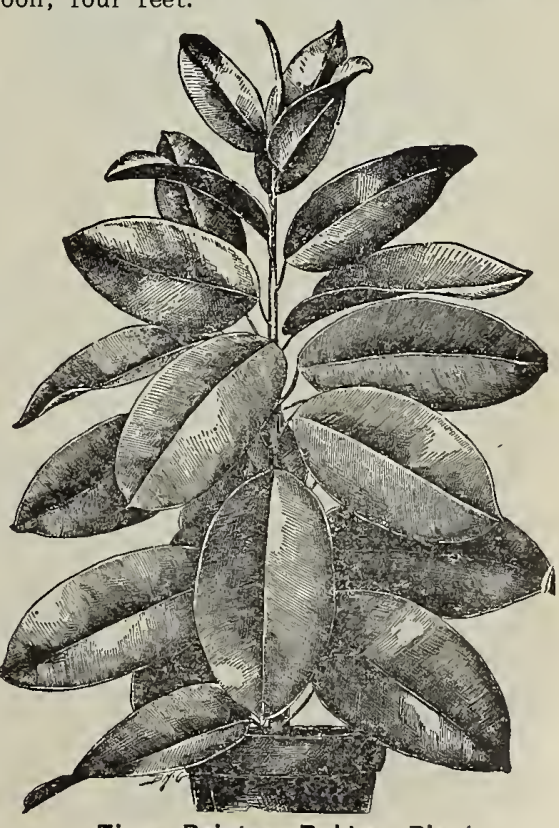

Flcus Belgica-Rubber Plant. 

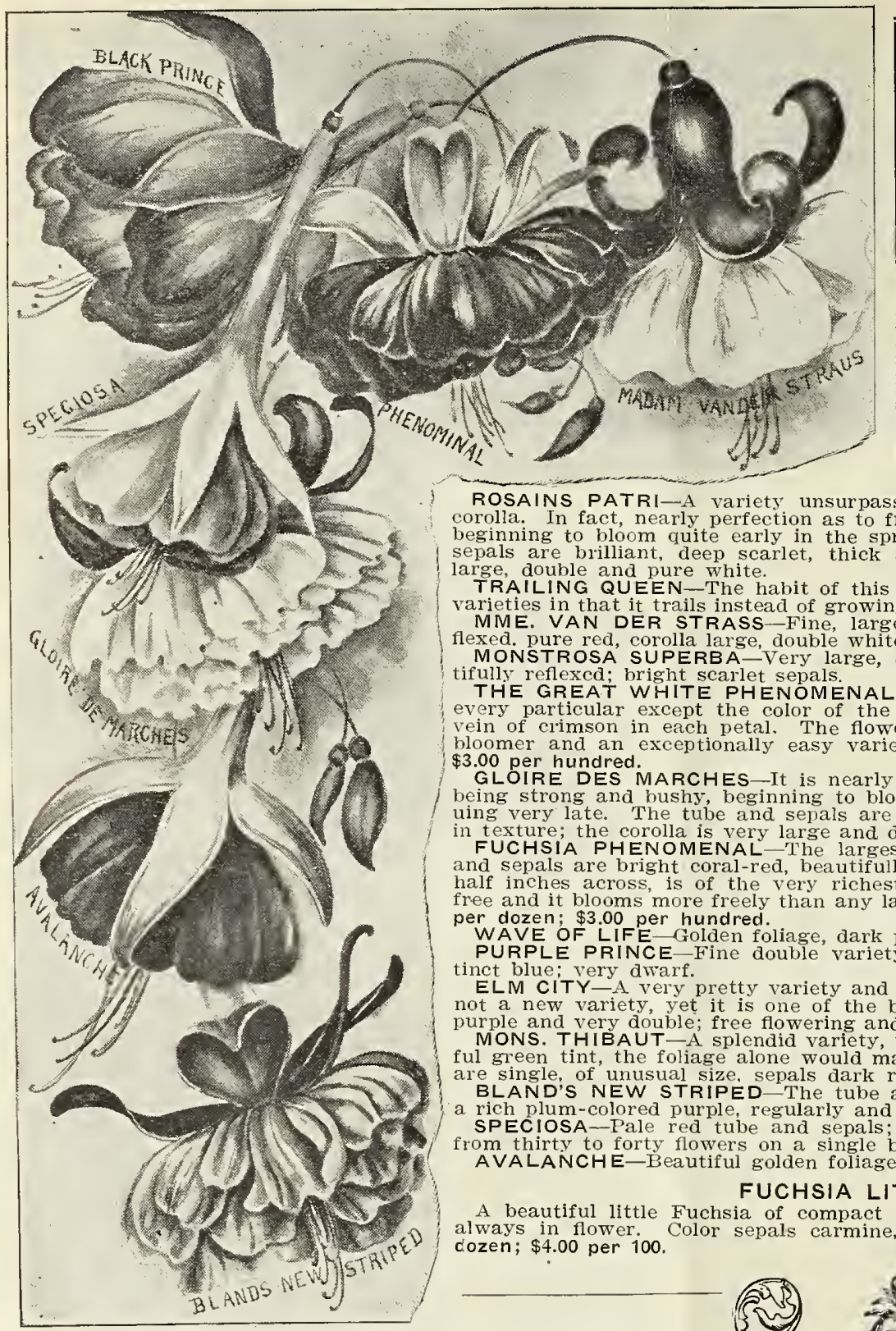

\section{FUCHSIAS}

Price, 40 centsper dozen ; $\$ 2.50$ per hundred, except where noted.

THE BLACK PRINCE-A misnomer as far as name is concerned, being of a bright, waxy carmine; tube and petals large and broad, with pale green tips; fully symmetrical habit and the best all around Fuchsia we know of.

TROPHEE-Double; buds quite round and beautiful deep red color; open flower, dark purple and very beautiful. One of the very finest of the Fuchsias.

ROSAINS PATRI-A variety unsurpassed among all the Fuchsias, with white corolla. In fact, nearly perfection as to free growing and habit; strong and bushy, beginning to bloom quite early in the spring and continuing very late Tube and sepals are brilliant, deep scarlet, thick and leathery in texture; corolla is very arge, double and pure white.

habit of this variety is much different from the other arieties in that it trails instead of growing upright. Pretty flowers borne in clusters. MIME. VAN DER STRASS - OHN MONSTROSA SUPERBA-Very large, double flowers; pure white corolla, beau-
MONed

THE GREAT WHITE PHENOMENAL FUCHSIA-The same as Phenomenal in every particular except the color of the flower, which is a pure white with one
vein of crimson in each petal. The flower is large and very double. It is a free veln of climson in each petal. The variety to grow. Price, 50 cents per dozen; $\$ 3.00$ per hundred.

GLOIRE DES MARCHES-It is nearly perfection as to free growing and habit, being strong and bushy, beginning to bloom quite early in the season and contining very late. The tube and sepals are brilliant deep scarlet, thick and leathery texture; the corolla is very large and double and pure white.

A largest Fuchsia we have yet seen. The tube and sepals are bright coral-red, beautifully formed. The corolla, nearly two and a half inches across, is of the very richest violet shade. The habit is remarkably ree and it blooms more freely than any large variety we have seen. Price, 50 cents per dozen; $\$ 3.00$ per hundred.

WAVE OF LIFE Golden foliage, dark purple single flower. A beautiful variety. PURPLE PRINCE-Fine double variety; sepals scarlet; corolla a beautiful disELM CITY - A wary. not a new variety, yet it is one of the best. Sepals a rich crimson; corolla deep

MONS. THIBAUT-A splendid variety, with large, handsome foliage of a delightful green tint, the foliage alone would make it worthy of cultivation. The flowers BLAND'S NEW STRIPED-The dark red, corolla rose-vermilion, tinted violet. Parple, regularly and distinetly striped red rose.

SPECIOSA-Pale red tube and sepals; dark red corolla, there frequently being AVALANCHE-Beautiful golden foliage, with a dark double violet-purple corolla.

\section{FUCHSIA LITTLE BEAUTY}

A beautiful little Fuchsia of compact and dwarf growth. A constant bloomer, always in flower. Color sepals carmine, corolla deep lilac. Price, 50 cents per

NOTICE TO SHOW THE GOOD ASSORTMENT OF FUCHSIAS WE CATALOG UE WE WILL SEND ONE

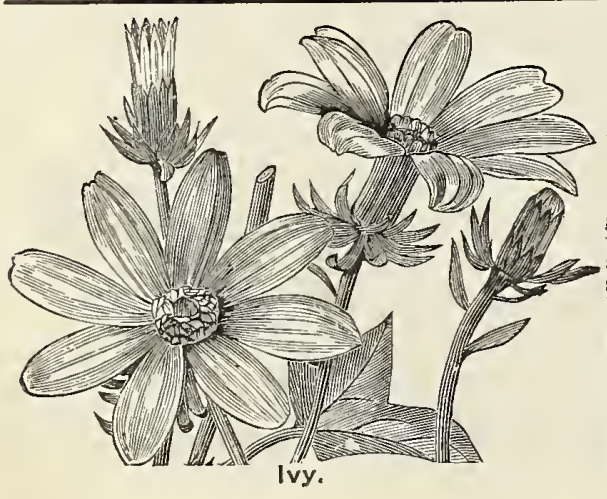

IVY-GERMAN

OR PARLOR

Price, 40 cents per oz.; $\$ 2.50$ per 100. MIKANIA SCAN DENS-A s trong growing cli m ber, and green foliage, suitable for large SENECIO SCAN. DENS-(New German or Parlor Ivy. A more rapid or sucglossy-green and flowers yellow, in clusters.

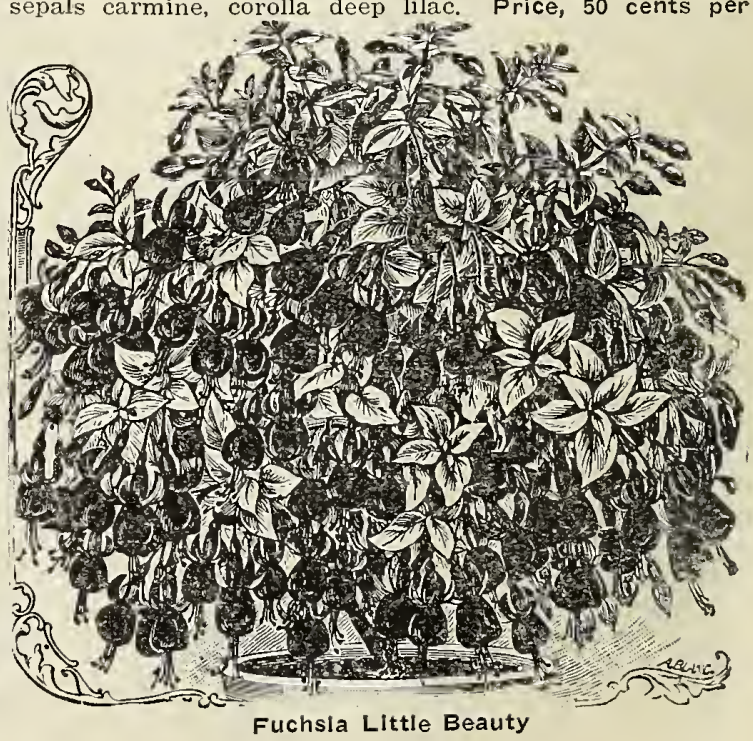




\section{Ferns, Decorative and Ornamental}

The Most Popular Fern, WHITMANII

The finest Fern yet introduced. This fine Fern received first award at the Society of American Florists. It is somewhat similar to the Piersoni, but more compact, more sturdy in its growth, and never running back to the old Boston leaf. Price, 21/2-inch pot plants, 50 cents per dozen; $\$ 3.50$ per hundred; strong 7-inch pot grown plants, $\$ 2.00$ per dozen; $\$ 15.00$ per hundred.

\section{PIERSON}

"Ostrich-Plume" Fern

The fronds grow in the most luxuriant manner, the pinnae subdividing, making miniature fronds, which are superimposed on the main fronds, looking as if two or even three were condensed in one. Price, .strong $21 / 2$-inch stock, 50 cents per dozen; $\$ 3.00$ per hundred; strong 4inch pot-grown plants, $\$ 1.50$

\section{PTERIS TREMULA}

(Shaking Fern.) The foliage of the Pteris varieties is large very graceful. It grows readily and very fast. Price, $21 / 2$-inch pots, 50 cents per dozen; $\$ 3.00$ per hundred.

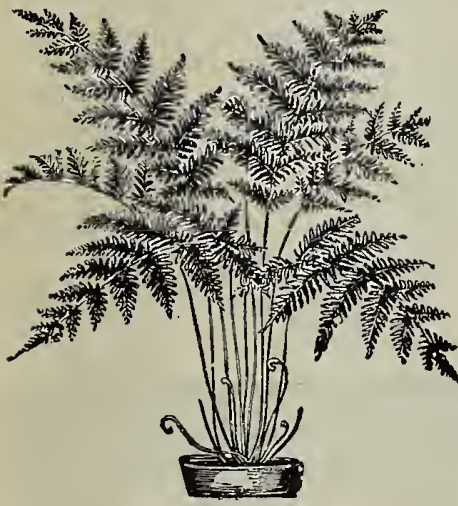

Pteris Tremula

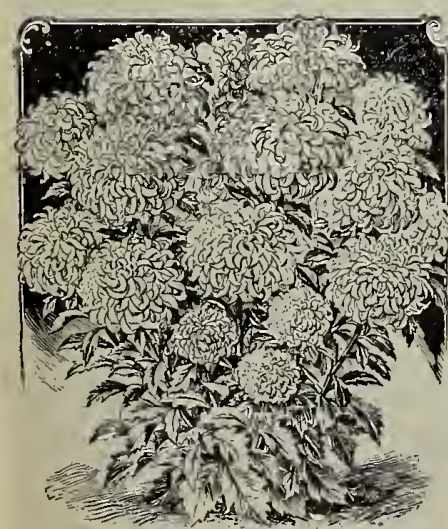

Feverfew, Little Gem

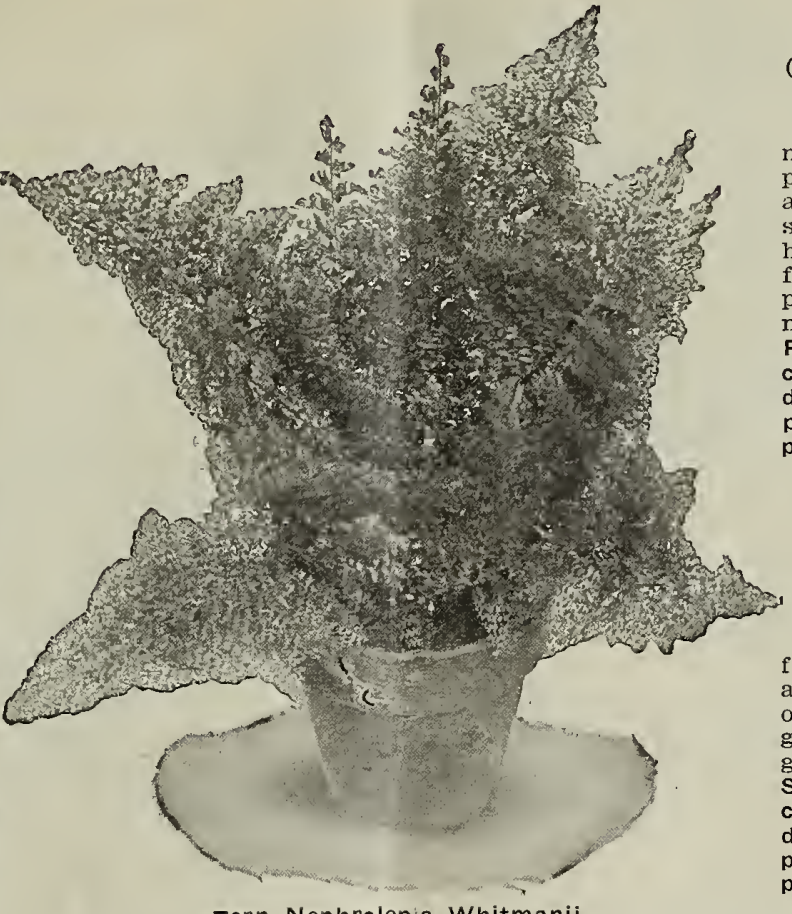

Fern Nephrolepis Whitmanii

\section{ADIANTUM VENOSUM}

The Beautiful Maiden Hair Fern. A very beautiful form of A. Cuneatum, having long, graceful fronds, with the ends of the ing long, graceful fronds, with the ends heads. fronds developed into bunching tasseled heads. having a little larger leaf, and stronger grower. Price, 50 cents per dozen; $\$ 3.00$ per hundred.

\section{SELAGINELLA EMILLIANA}

An upright growing moss, with numerous feathery stems branching from the base and forming a dense tuft. Well grown plants attain twelve to eighteen inches in height. We know of no moss superior to it. We put this moss in with the page of Ferns, as the character is very much like the Fern and is used dozen; $\$ 3.00$ per hundred.

\section{GLECHOM A HEDERACEA} Variegated Ground Ivy.

The foliage of this charming novelty is a bright The marked with pure white and has a refreshing fragrance similar to mint. Price, 40 cents per dozen; $\$ 3.00$ per hundred.

\section{LITTLE GEM FEVERFEW}

It is very dwarf, attaining a height of only eight or ten inches; flowers are large, of a more perfect form and of the purest white. Price, 50 cents per dozen; $\$ 3.00$ per hundred.

\section{GENISTA CANARIENSIS} (Fountain of Gold)

This beautiful plant well deserves the great popularity it has gained in the past two years. The drooping branches are covered with delicate sage-green foliage and every twig tipped with a long raceme of exquisite pea-shaped blossoms of a pure canary color, "Fountain of Gold." Price, strong $21 / 2$-inch pots, 50 cents per dozen; $\$ 3.00$ per hundred.

NOTE-We wish to call special attention to our fine stock of Asparagus Plumosus, strong two-and-one-halfinch stock ready for a shift into four-inch.

\section{BOSTON FERN}

(Nephrolepsis Exaltata Bostoniensis)

This plant is so well known it needs no description. No other plant is used so extensively, nid no other makes as fine a specinten plant. The droopins habit of the long, graceîul fronds makes it an excellent plant to moiv as a single specimen for the table or pedestal. Price, strong $21 / 2$-inch stock, 50 cents per dozen; $\$ 3.00$ per hundred; strong 4-inch pot grown plants, $\$ 1.50$ per dozen; $\$ 12.00$ per 100.

\section{THE DWARF BOSTON FERN}

(Nephrolepis Scotti)

A compact dwarf form of the favorite Boston Fern, in general appearance very much like the original form. It is just as gracefully drooping in habit of growth, but is more compact. Strong, $21 / 2$-inch pot plants, 50 cents per dozen; $\$ 3.00$ per hundred; strong 4-inch pot grown plants, $\$ 1.50$ per dozen; $\$ 12.00$ per hundred.

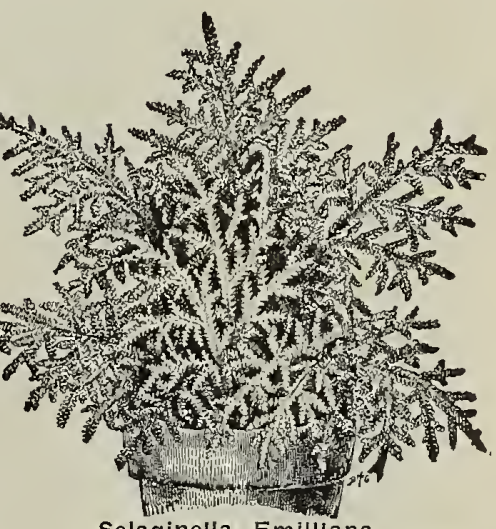

Selaginella Emilliana

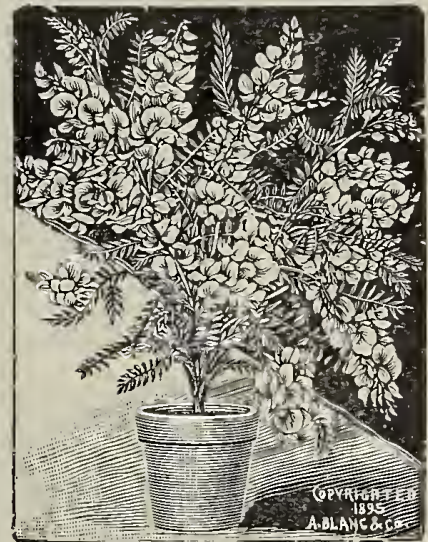

Genista Canariensis. 


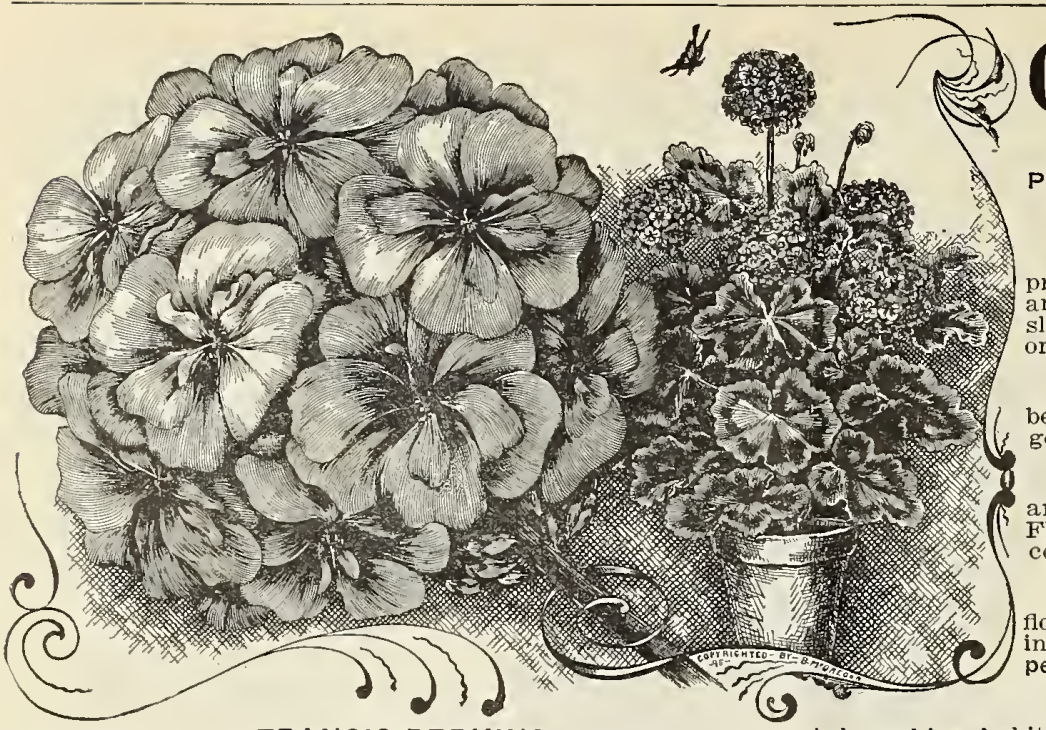

\section{GERANIUMS DOUBLE}

Price, 50 cents per dozen; $\$ 3.00$ per hundred $\$ 25.00$ per thousand (except where noted).

\section{ALPHONSE RICARD}

A strong grower, dwarf and branching, and producing flowers in great masses. Both floret slightly doubled, and color a brilliant shade of orange-red.
MARQUIS DE MONTMORT

Deep crimson carmine. A very novel and beautiful shade. A strong, robust grower with good foliage. BUCKNER

A new Geranium of the large-flowering type and one that has proved to be a fine bedder. center. Plant dwarf and bushy.

The giant among Geraniums. Color of the flower is a bright vermilion-red of most striking shade. Price, $\$ 2.50$ per hundred; $\$ 20.00$ per thousand,

\section{BEAUTE POITEVINE}

FRANCIS PERKINS

This is the best double pink bedding Geranium; plant is an extra strong, vigorous grower, throwing out tall spikes of large, well formed flowers of a bright pink color. Price, $\$ 2.00$ per hundred; $\$ 18.00$ per thousand.

\section{HETERANTHE}

(Double Gen. Grant.) A splendid variety for bedding, the clear vermilion-red of its flowers showing well above compact, sturdy foliage. Price, $\$ 2.50$ per hundred; $\$ 20.00$ per thousand.

\section{JOHN DOYLE} It is a strong, vigorous grower, throwing its truss up well
above the foliage, of enormous size, and of the richest brilliant vermilion-scarlet.

\section{JEAN VIAUD}

Very large semi-double blooms borne in large trusses well above the foliage; individual floret large, color bright rosypink, with distinct white blotch in the center; habit dwarf, compact, very vigorous and exceptionally free blooming.

\section{MRS. LAWRENCE}

Clear, healthy foliage, dwarf compact habit of growth, wonderfully free in flowering. The color is an artistic shade of bright satiny salmon pink, slightly tinged white.

\section{BERTHA DE PRESSILY}

A most beautiful shade of silver-rose of exquisite brightness; the blooms are extra large, very double; the habit is dwarf, robust and branching, continually in bloom.

\section{FLEUVE BLANC}

A new Geranium of the large flowering type and one that has proved to be a fine bloomer. Flowers purest white; not a trace of coloring at the center. Very free flowering, always a perfect mass of white. Plant dwarf and bushy, with crested foliage.

\section{SINGLE GERANIUMS}

Price, 50 cents per dozen; $\$ 3.00$ per 100 (except where noted). GRANVILLE

A fine bedding variety, with large flower trusses. The color is a clear pink. One of the best Geraniums for general use of our knowledge.

MRS. E. G. HILL

For those unacquainted with the variety we would say it is a most dis tinct and pleasing shade of salmon, with light shading to the center. The inest salmon-flowered Geranium to date.

\section{TELEGRAPH}

A large flowering single scarlet. Flowers are in immense trusses, upon tall, stiff stems. A bushy, compact grower and a great bloomer.

\section{L'AUBE}

Eriormous sized trusses, large, round florets, pure snow-white, retaining ts pureness the entire season; in freedom of bloom, splendid habit and growth of plant this variety resembles the excellent double white variety

MRS. J. M. GAAR

Absolutely perfect as a bedding variety; never burns; is of dwarf, com pact habit, and in freedom of bloom is superior to all whites, and equal to felt vrant in a white bedder.

\section{JACQUERIE}

A most beautiful shade of deep carmine-red; immense trusses on exceptionally long stems; very vigorous grower and unsurpassed as a bedder. Price, 50 cents per dozen; $\$ 3,50$ per hundred.

\section{PAUL CRAMPE}

A most brilliant shade of vermilion-scarlet; foliage deep rich green with a distinct zone; habit strong, compact and vigorous. This is the iree blooming single we have. Price, 50 cents per dozen; $\$ 3.50$ per hundred. NOTE-Let us quote you on Geraniums in our selection of variety, all taken from the best varieties.
It is very dwarf and compact and of a very deep magenta color, others with the outer COMTESSE DE HARCOURT

ant, pure snow-white florets, beautifully formed nd abundantly produced in large trusses; stands the sun MISS KENDALL

Exquisite dark cerise, shading to scarlet in the center; large trusses.

\section{LA FAVORITE}

\section{S. A. NUTT}

the flowers are of perfect shape and ice, 40 cents per dozen; $\$ 2$.

MME. LOUISE ABBENIA

\section{MRS. LANDRY}

A strong grower with heavy, thick foliage resembling its

Rich dark crimson.

roduced in great number; close, compact habit. MARQUIS DE CASTELLANE

A giant among Geraniums. Trusses of bloom five to seven inches across; color deep rosy-scarlet, shading into pure scarlet at the edge of the upper petals. M. CANOVAS 


\section{FA N C Y GERA N I U S}

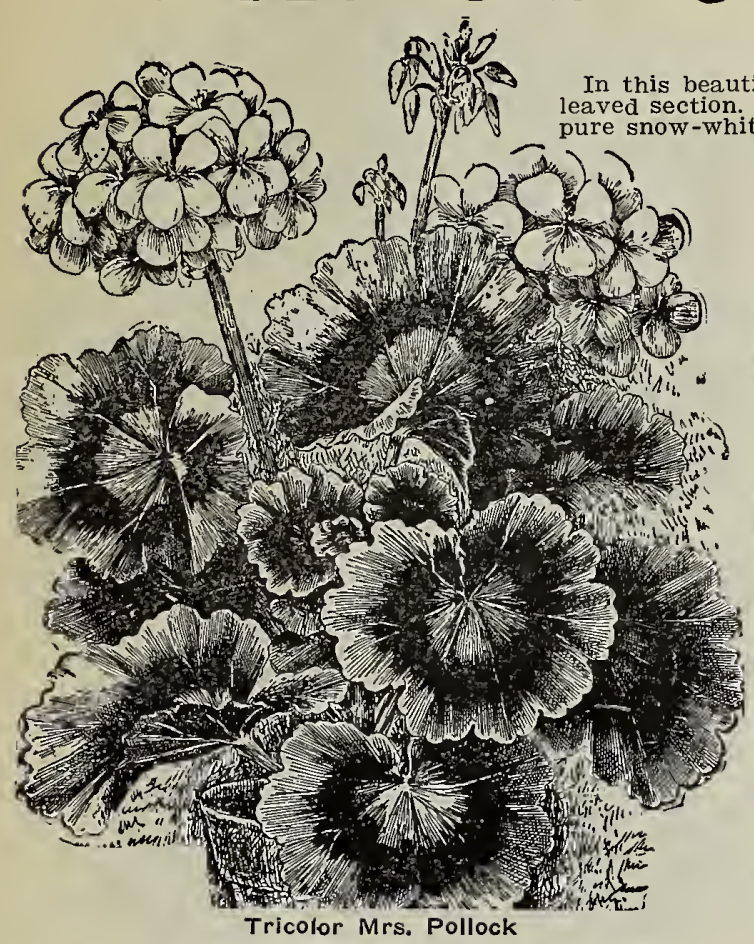

SWEET=SCENTED GERANIUMS

Price, 40 cents per dozen; $\$ 3.00$ per 100 (except where noted) LEMON-SCENTED-Small leaves, delightfully lemon scented; one of the most pleasing varieties.

MRS. TAYLOR-Dark green foliage of a peculiar fragrance; flowers are scarlet, shaped like a Pelargonium, and borne in great profusion.

ROSE-Needs no description. Indispensable in the formation of bouquets. Beautiful pink flowers, borne in clusters. BROAD-LEAF ROSE-This variety res, borne in clusters. Rose Geranium, having a thicker leaf not so deeply cut.

SKELETON-LEAF ROSE-SCENTED (or Dr. Livingston)The most popular scented Geranium. It is the same as the Rose in all points except the leaf is more deeply cut, or
Fern-like. Price, E0 cents per dozen; $\$ 4.00$ per 100 .
Double Pink Silver-Leaf Geranium MRS. PARKER

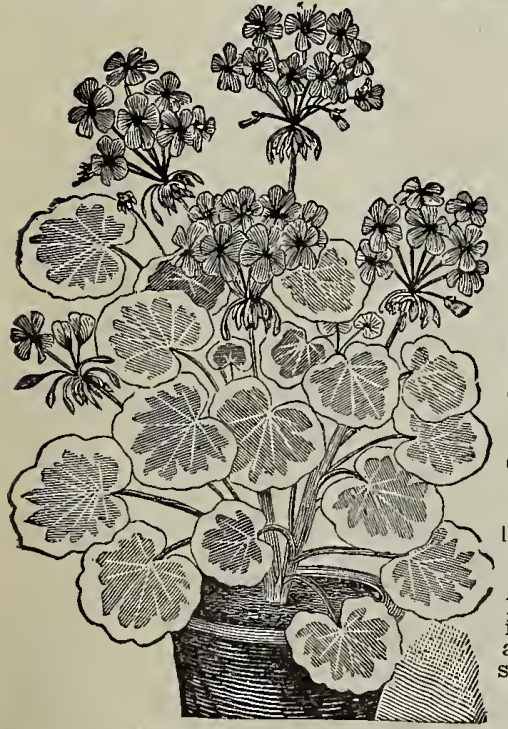

Mountain of snow

\section{IVY GERANIUMS}

Price, 50 cents per dozen; $\$ 3.00$ per 100 . New Double White Ivy Geranium, JOAN OF ARC

The flowers are perfectly double. white as snow, and literally cover the plant when in full bloom.

\section{FLOURENS}

Flowers very large and double; petals large, Flown heavily shaded rose. The Splendid New Ivy Geranium,

MRS. HAWLEY
The flowers are large, in fine trusses on long

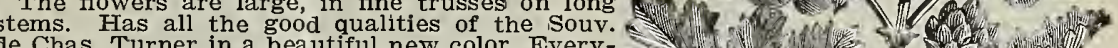
de Chas. Turner in a beautiful new color. Everyone will appreciate this beautiful novelty. LA ROSIARE

Fine, strong grower, with large double bloom. Color clear pin

REMARKABLE

A good strong growing variety.

$$
\text { P. CROZY }
$$

A grand hybrid between the Zonals and Ivies, having the foliage of the former, but very heavy in texture, while the forms of truss and florets ing the color is soft, bright scarlet.

\section{CAMILLE DOUCET}

Flowers large, rosy-salmon, lightly marked red

JUSTICIAS

JUSTICIA SANGUINEA-(Brazilian Plume Plant.) A strong, upright grower producing fine plume-like pink flowers, the end of each petal drooping in a charming manner. Price, 50 cents per dozen; $\$ 3.00$ per hundred.
NEW DWARF JUSTICIA "VELUTINA"-This new sort which is now grown so extensively by Parisian florists begins to bloom when the plant has only three or four leaves. Flowers beautiful shell-pink. If pinched back occasionally it makes very dwarf, stocky plants. Foliage is highly ornamental, being heavy in texture and
cents per dozen; $\$ 3.00$ per hundred. 


\section{HELIOTROPES}

Price, 50 cents per dozen; $\$ 3.00$ per $100 ; \$ 25.00$ per 1,000 . QUEEN OF THE VIOLETS

This Heliotrope is without doubt the finest dark variety cultivated. A good, strong grower.

\section{FLORENCE NIGHTINGALE}

Splendid market kind; healthy, flowers bright lavender, good

MADAME DE BLONAY

Fine, large strong foliage, very large trusses of pure white flowers.

\section{ALBERT DELEAUX}

Foliage is a bright golden-yellow, marked slightly with a delicate green.

\section{MADAME BRUANT}

Immense panicles of very large flowers, rich purple, with large white eye.

\section{The Giant Flowering Heliotrope \\ PICCIOLA}

Rosy-violet, indeed, almost red, with a distinct white center showing upright growth, producing immense heads of flowers. CZARINA

Another good dark one, deep purple with white eye and very fragrant.

\section{New Double Blue Lobelia \\ KATHLEEN MALLARD}

Originated as a chance seedling from Lobelia Speciosa and has very large double flowers of an intense rich deep blue color. It is a most desirable plant, which meets with favor with every-
one. Readily propagated from cuttings and divisions. 50 cents per dozen; $\$ 3.00$ per 100 .
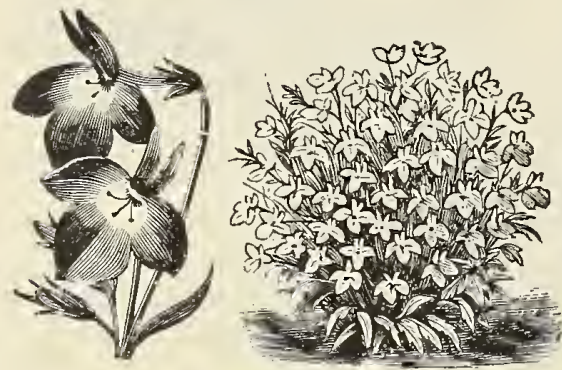

LOBELIA GRACILIS

A fine plant to border your Canna or window box it cannot be surpassed. It grows to a height of four to five inches and is a mass of clear blue mass of clear blue most showy little bordering plants we have listed. Price, 40 cents per dozen; $\$ 2.50$ per Lobelia Gracilis.

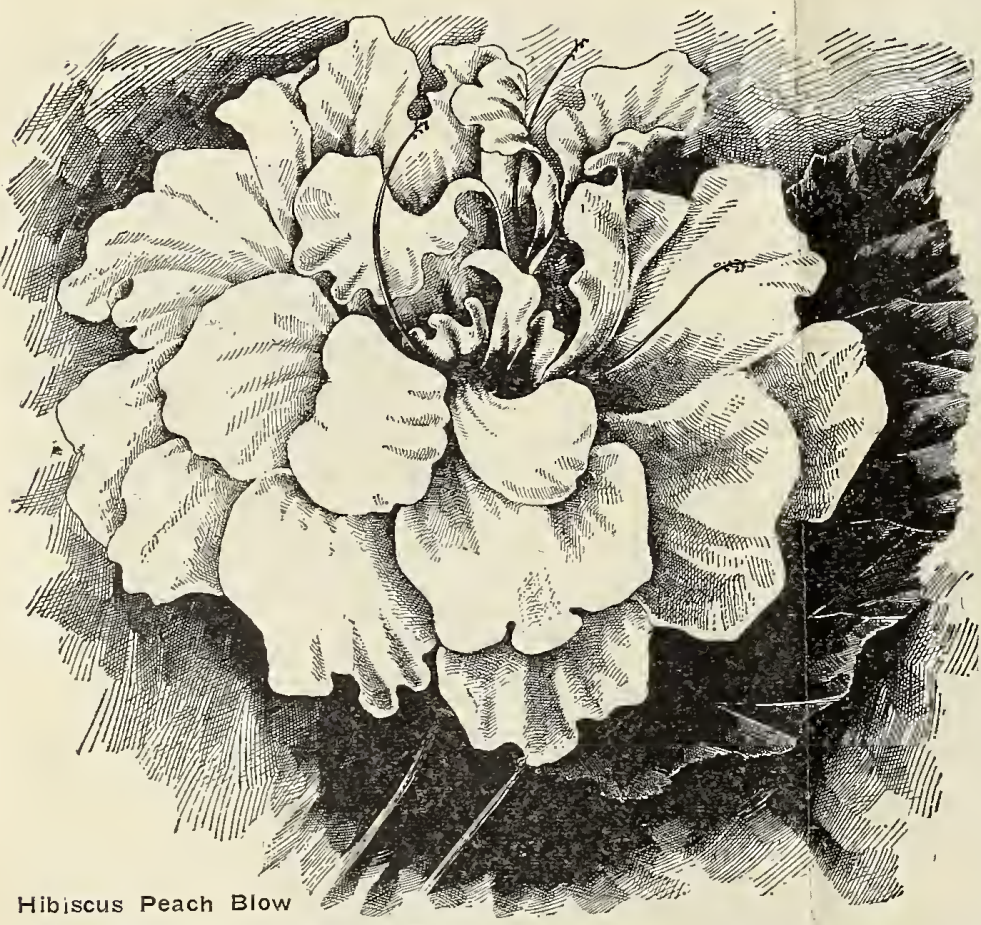

COLLERII

A remarkably new and distinct variety, introduced from the South Sea Islands. Flowers of a buff-yellow, with a crimson-scarlet base, and peculiarly handsome.

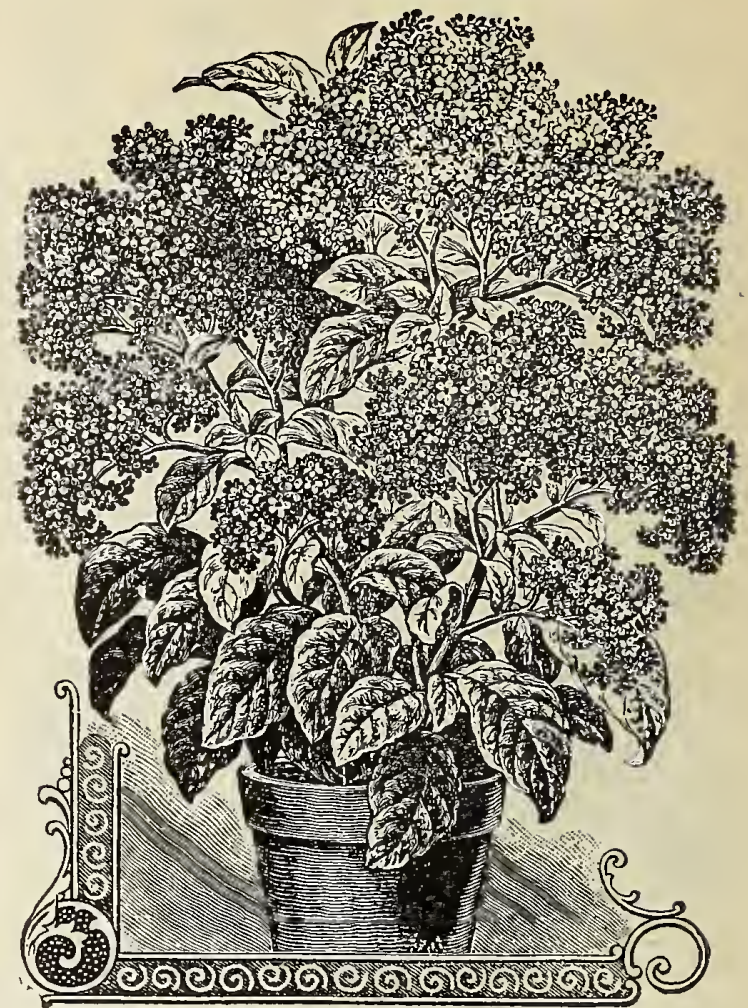

Heliotrope Czarina.

IMPATIENS SULTAN

The flowers are of a brilliant rosy-scarlet color, of a peculiarly distinct but most effective hue. .Price, 50 cents per dozen; $\$ 3.00$ per hundred.

IMPATIENS HOLSTII

The newest Balsam offered to date. It is a strong grower, quite distinct from any other impatiens. The flowers are a brilliant vermilion color, a fine contrast to the dark green foliage. Price $50 \mathrm{c}$ per doz.; $\$ 3$ per 100 . IMPATIENS QUEEN

Strong grower, flowers white with pink eye. HIBISCUS

Price, 50 cents per doz.; $\$ 3.00$ per 100 ; stron 4 -inch, 12 to 15 inches high, $\$ 1.00$ per doz.; $\$ 8.00$ per 100 .

\section{PEACHBLOW}

This is one of the finest plant novelties offered in recent years. It is a "sport" from the double red Hibiscus Rosea Sinensis; the flowers are double and from four to five inches in diameter; of a charming rich, clear pink color, with a small deep crimson center. Price, 50 cents per dozen; $\$ 3.00$ per hundred. Strong four-inch pot plants, fifteen to eighteen inches h:gh, $\$ 1.00$ per dozen; $\$ 8.00$ per hundred.

SUB VIOLACEOUS

Flowers of enormous size, of a beautiful carmine, tinted with violet; probably the largest flower of the Hibiscus family.

\section{GRANDIFLORA}

Rich glossy foliage blooming profusely through the summer, literally covering the plant with scarlet-crimson flowers.

MINIATUS SEMI-PLENA

Large, semi-double brilliant and attractive bright vermilion-scarlet; ought to be in every garden.

\section{VERSICOLOR}

A variety combining in its flowers all colors f the whole family, being handsomely striped crimson, buff, rose and white. AURANTIACA

Large, double orange-colored flowers; an early and profich

\section{CARMINIATUS PERFECTUS}

Full round flowers of perfect shape, and of a rich, soft carmine-rose, with a deep crimson eye. $A$ beautiful free blooming variety. CRIMSON EYE-Hardy Hibiscus

A fine, large, single white hardy Hibiscus with crimson eye. Perfectly hardy and robust grower. Price, 50c per doz.; $\$ 3.00$ per 100 . Strong 3-year-old roots, $\$ 1.00$ per doz.; $\$ 8.00$ per 100. 


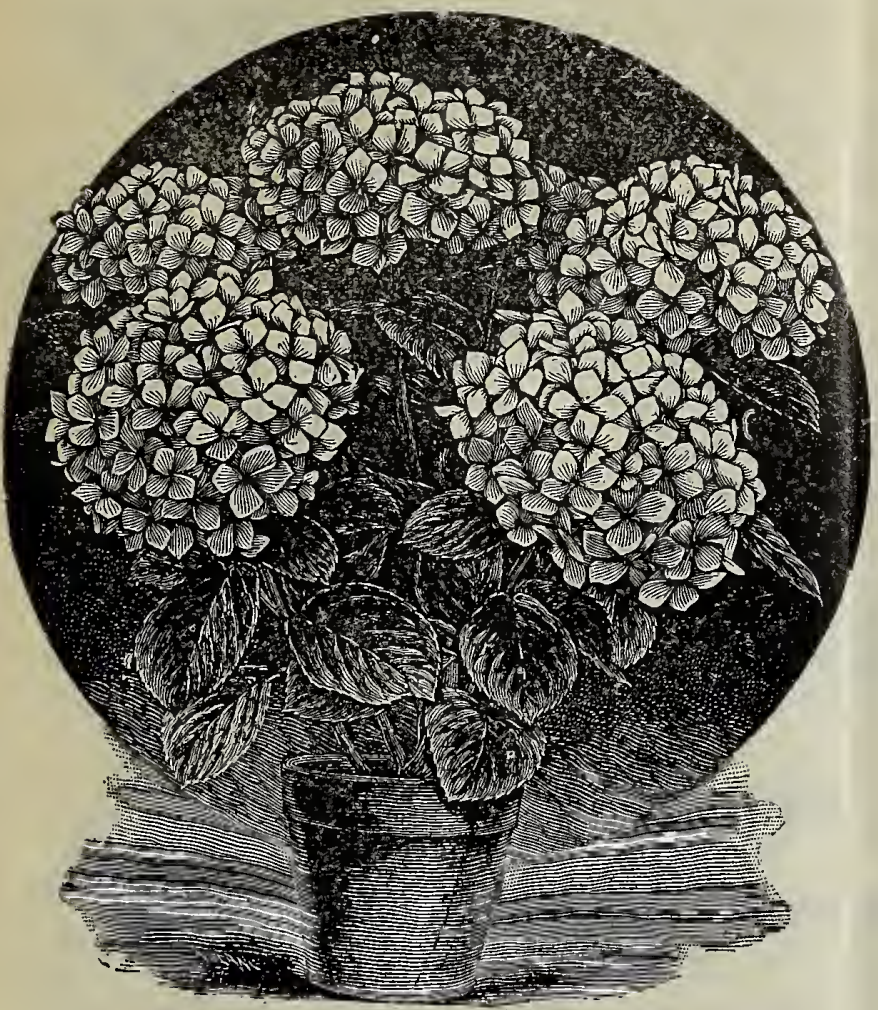

Hydrangea Monstrosa

\section{HYDRA N GEA S}

\section{HYDRANGEA MARIESII}

It is especially remarkable for the large size and distinct color of its sterile flowers, which are fully three inches across, of a light pink color tinted with mauve. Price, 50 cents per dozen; $\$ 3.00$ per hundred. HYDRANGEA THOMAS HOGG

A pure white variety. One of the finest plants for HYDRANGEA JEANNE D'ARC A new variety of exceptionally good merits. It is a
variation of the old favorite Thomas Hogg, but having the dark reddish-brown stem of Ramus Pictus. The flower is pure white and very effective against the
dark green foliage. Price, 50c per doz.; $\$ 3.00$ per 100 . HYDRANGEA OTASKA MONSTROSA

This is by far the best of all Hydrangeas. The color is at first a deep rich pink, gradually changing color most a snow-white. Price, 50 cents per dozen; $\$ 3.00$ per $100 ; \$ 27.50$ per 1,000 .

\section{Hardy Hydrangea,
ARBORESCENS GRANDIFLORA}

Snowball Hydrangea

A grand addition to the summer flowering hardy shrubs. Comes into bloom just at a time when there is a scarcity of outside white flowers, along through July and August. Makes a plant much like the common Hydrangea, but blooms with purest snow-white flowers shaped much like the Snowball flower, but much larger and more attractive. Nothing in the hardy shrub line approaches it in freedom of bloom, duration of flower, and value as a cut flower, or as a plant for single specimens or groupings. Price, strong $21 / 4$-inch pot plants, 50 cents per dozen; $\$ 3.00$ per $100 ;$
$\$ 25.00$ per 1,$000 ;$ sizes 10 to 12 inches high, single stems 60 cents per dozen; $\$ 5.00$ per 100 ; 15 to 18 inches, bushy, $\$ 1.00$ per dozen; $\$ 8.00$ per $100 ; 18$ to 24 inches, $\$ 1.50$ per dozen; $\$ 12.00$ per 100 . Hardy Hydrangea,

PANICULATA GRANDIFLORA

This is one of the most hardy shrubs in cultivation. It attains a height of three or four feet, and is perfectly hardy in all parts of the country. The hower are white, borne in immense pyramidal panicles nearfourteen inches, 60 cents per dozen; $\$ 4.00$ per hundred.

\section{JASMINES}

GRANDIFLORA-(Catalonian Jasmine.) Flowers fragrance. Price, 50 cents per dozen; $\$ 3.00$ per hundred.

REVOLUTUM, Yellow Jasmine-A strong, climbing plant with glossy leaves and single, deep yellow, fragrant blossoms. Price, 50c per dozen; $\$ 3.00$ per 100 .

MAID OF ORLEANS-A very attractive sort with good sized double flowers, blooming profusely all summer, shining pale green foliage. Much easier to handle mer, shining pale green ioliage. and a whole more desirable. Price, 50 cents per doz.; $\$ 3.00$ per 100 . Strong 4 -inch plants, $\$ 1.00$ per dozen; $\$ 8.00$ per 100 .
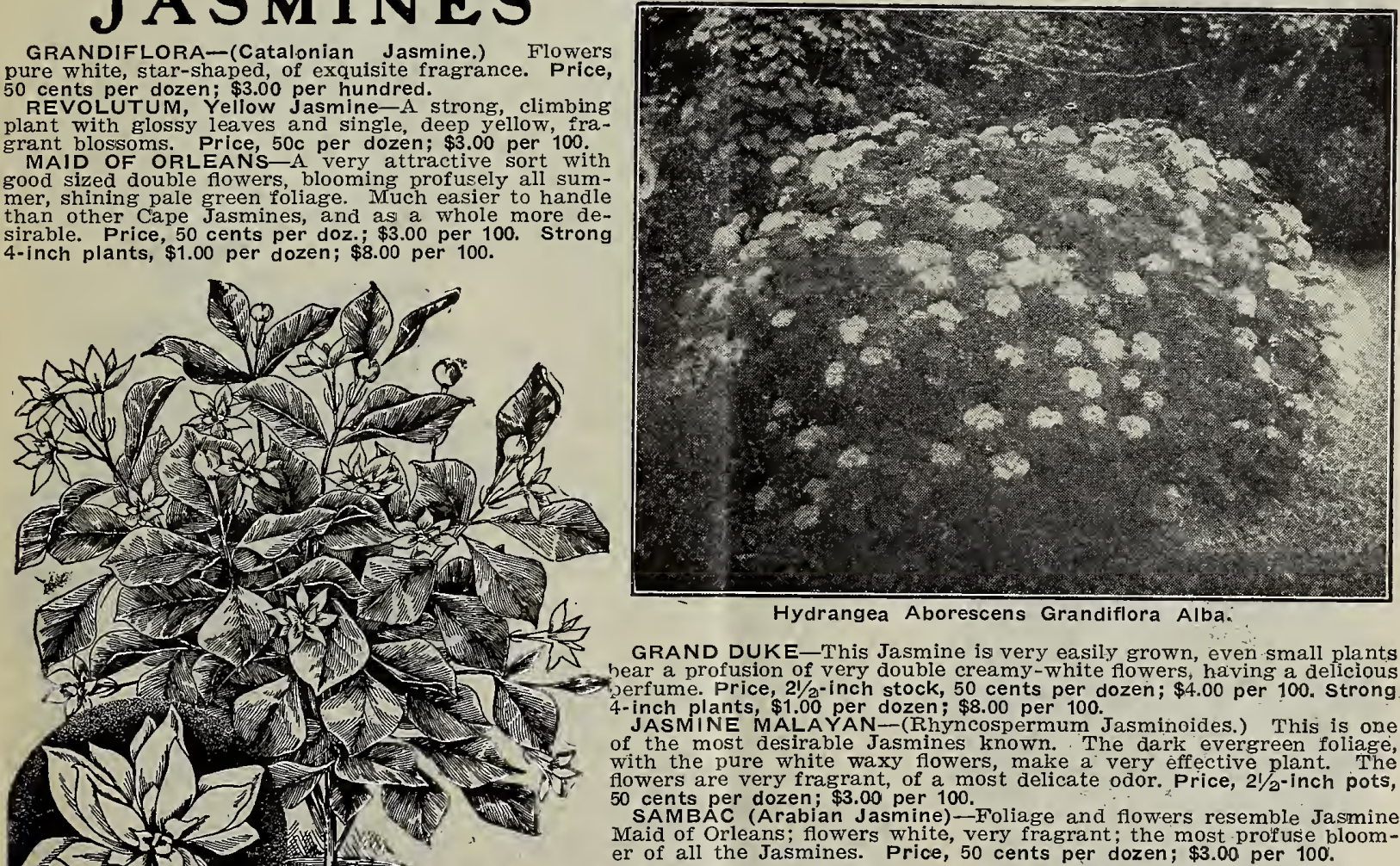

Hydrangea Aborescens Grandiflora Alba:

GRAND DUKE-This Jasmine is very easily grown, even small plants hear a profusion of very double creamy-white flowers, having a delicious
erfume. Price, $21 / 2$-inch stock, 50 cents per dozen; $\$ 4.00$ per 100 . Strong 4 -inch plants, $\$ 1.00$ per dozen; $\$ 8.00$ per 100

JASMINE MALAYAN-(Rhyncospermum Jasminoides.) This is one of the most desirable Jasmines known. The dark evergreen foliage with the pure white waxy flowers, make a very êffective plant. The lowers are very fragrant, of a most delicate odor. Price, $21 / 2^{-}$-inch pots,

50 cents per dozen; $\$ 3.00$ per 100 . Foliage and flowers resemble Jasmine Maid of Orleans; flowers white, very fragrant; the most profuse bloomer of all the Jasmines. Price, 50 cents per dozen; $\$ 3.00$ per 100.

CAPE JASMINE-The rose-shaped flowers are pure white, waxy appearanee and tuberose scented. The glossy everrative plant, even when not in bloom. Price, size 12 to 18 Inches, bushy, $\$ 2.00$ per dozen; $\$ 15.00$ per 100 .

JASMINE GRACILLIUM-A new Jasmine and remarkable for its freedom of bloom. Beautiful pure white flowers borne in clusters. Delightfully fragrant. In bloom from October to February. dred.

"Cape Jasmine" 


\section{THE TRUE MOONFLOWER-Ipomea Grandiflora}

This plant has become very popular, and it certainly is a wonderful annual climber. The flowers are immense, pure white, sweet-scented, five inches in diameter, borne very profusely, and as they open at night are very striking. Price, 50 cents per dozen; $\$ 3.00$ per hundred.

\section{GIANT MOONFLOWER-(Ipomea Maxima)}

This grand new Moonflower is a decided improvement over the old standard variety Ipomea Grandiflora. The flowers are more than twice the size of the old variety, oftentimes measuring from six to sever

\section{MANETTIA BICOLOR}

A rapid and beautiful climber. The flowers are from an inch to an inch and a half in length, of the most intense scarlet, shading into flame, tipped with bright golden-yellow, and are covere founded with the old Manettia-Cordifolia, as it is far superior to the old variety. Price, 50 cents per dozen; $\$ 3.00$ per hundred.

\section{LINUM TRIGYNUM}

A winter-blooming plant of great beauty, producing in the greatest profusion very large and very showy blooms of a bright yellow color. The flowers are about the size of a Morning Glory.
price, 50 cents per dozen, $\$ 3.00$ per hundred.

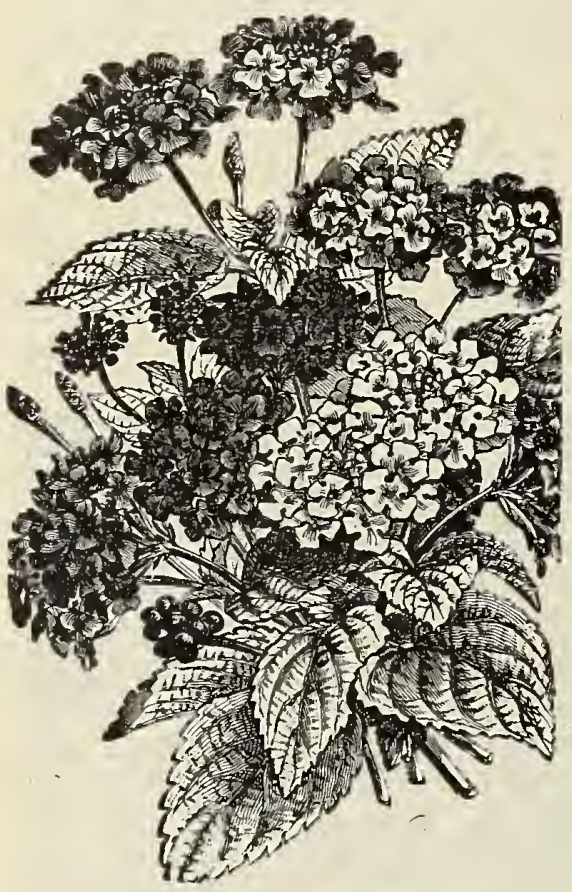

Lantana M. Schmidt.

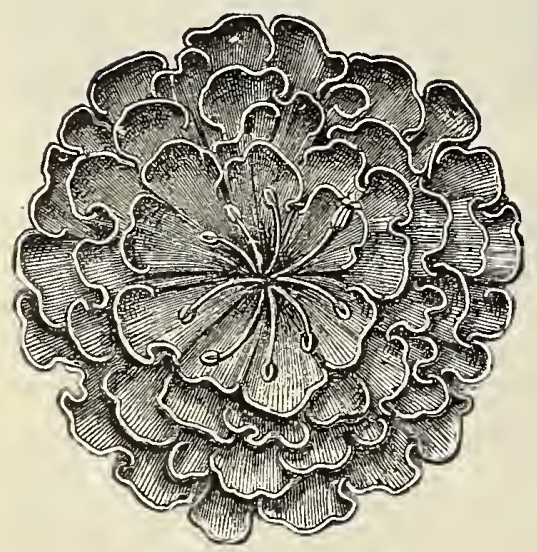

Double Nasturtlum.

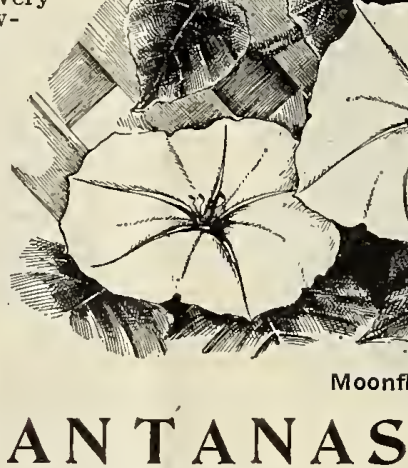

Price, 50 cents per dozen; $\$ 3.00$ per hundred.

ALBA PERFECTA-Pure white; ompact habit.

GRAND SULTAN-Dark red with butter-yellow.

LEO DEX-Deep purple.

COUNT BIENCOURT-Lilac and yellow.

HARKETT'S PERFECTION Foliage variegated with yellow: ers lilac.

MICHAEL SCHMIDT-Flowers fresh and sparkling; of a brilliant yellow, passing into a pure ver-

ULTIMA-A fine strong growing yellow.

\section{Weeping Lantana}

This plant has a most graceful drooping habit, grows very rapidly and blooms continually summer and winter, producing large clusters of flowers of the most delicate lilac or rosy-pink; foliage a cents per dozen; $\$ 3.00$ per hundred.

\section{DOUBLE (DWARF)}

\section{NASTURTIUM}

Prlce, 50 cents per dozen; $\$ 3.00$ per hundred.

A most atractive and deliciously scented plant producing large double flowers throughout the winter and summer seasons. Fine for edging or bedding.

DOUBLE YELLOW-Yellow, with g rich crimson-feathered blotch on each segment.
DOUBLE CRIMSON-Solid crimson.

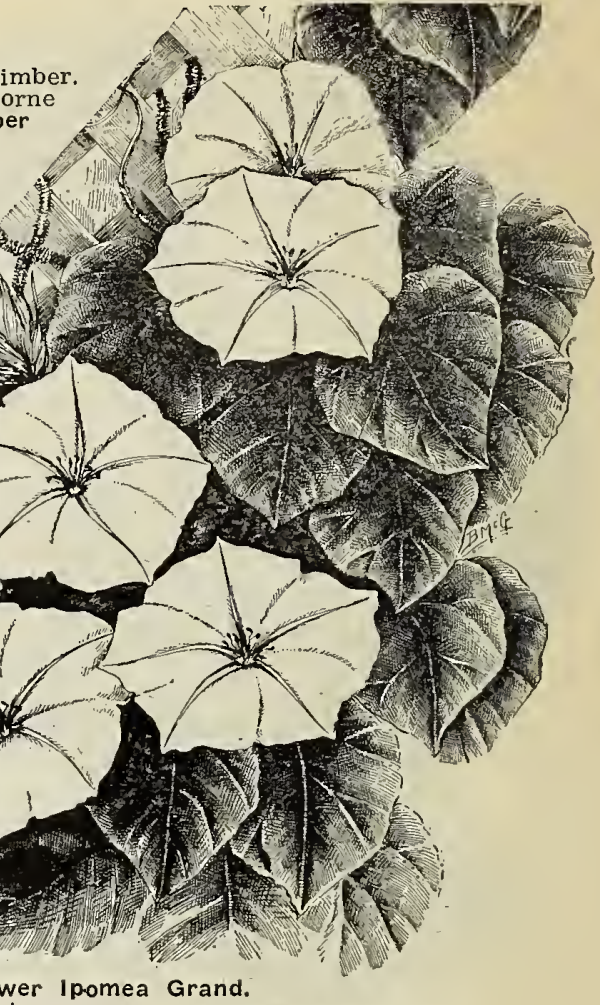

LEMON-American

Wonder, or Ponderosa

It is a true ever-bearing variety. The tree has fruit in all stages of development, from the size of a pea up to the ripe fruit, showing it to be a true everbearer. In addition to its fruit-bearing qualities it makes a very handsome plant for house culture. The dark green foliage is very large and handsome and the pure waxy flowers with yellow stamens are nearly as fragrant as orange blossoms Which they oreatly resemble. Prlce, 21/ Inch stock, 50 cents per dozen. $\$ 3.00$ per Then plants, $\$ 1.25$ per dozen; $\$ 10.00$ per 100 .

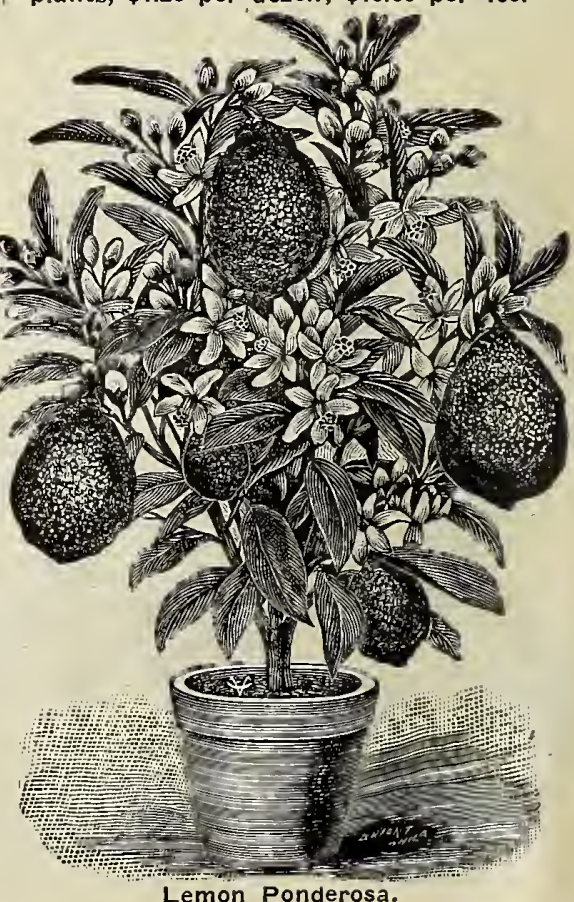




\section{CHINESE PRIMROSE}

Price, 50 cents per dozen; $\$ 3.00$ per 100

PRIMROSE ALBA-Flowers pure white, the foliage green. PRIMROSE RUBRA-Purplísh-red, whíte eye; fine strong grower.

P. KERMESINA SPLENDENS-Bright carmine-pink, yellow. COCCINEA-Bright red, large flowers, beautifully

fringed. red.

THREE NOVELTIES-60 cents per dozen; $\$ 4.00$ per 100 .

Orange King (new), rich orange-salmon. His Majesty (new)

fringed crimson. Sutton's Duchess, white with rosycarmine zone; yellow eye. MEXICAN PRIMROSE

ROSEA-The pink Mexican Primrose. A splenđid variety. Price, 50 cents per dozen; $\$ 3.00$ per hundred.

THE BABY PRIMROSE-(Primula Forbesii)

Wonderfully free-blooming plant, to flower as soon as oorne. Flowers of a delicate rosy-lilac, with eye of pale gold; produced in

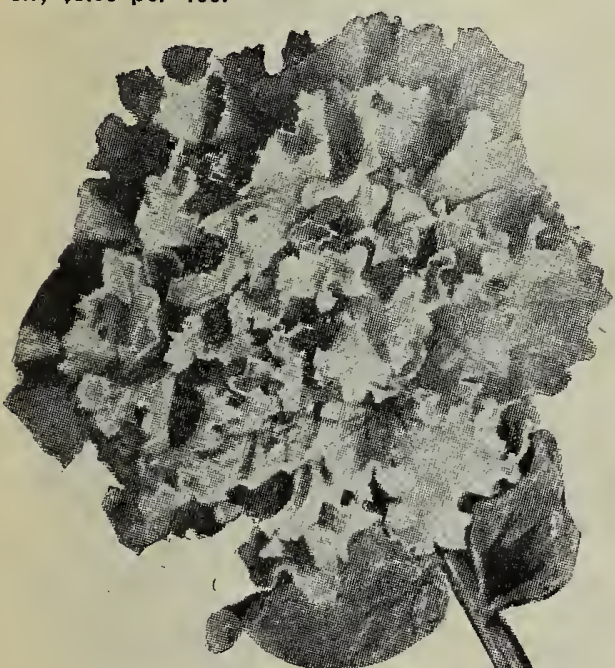

Double Fringed Petunias

DOUBLE FRINGED PETUNIAS

Price, 50 cents per dozen; $\$ 3.00$ per hundred. Mixed varietíes not named, $\$ 2.50$ per 100.

PINK BEAUTY-Large, clear pink.

MAJESTIC-Rích, deep purpl

DEFENDER-Pure white; very double.

GEM-Blotched, white and crimson.

VESUVIUS-Solid color; very dark.

SEAFOAM-Best of double whites.

ACHILLEA-Bright purple, mottled with

FAVORITE-Beautiful lavender on outer petals, becoming purple towards the center.

STRIKING-Best of the variegated varie-

ties; deep purple streaked with whíte.

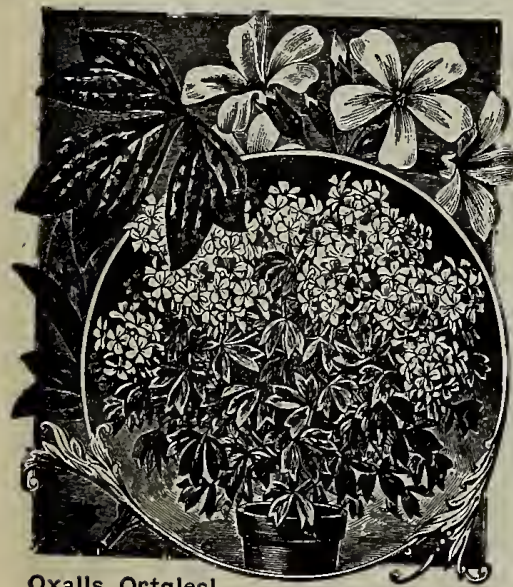

Oxalls Ortglesl
OLEANDER

LILLIAN HENDERSON -Flowers double white. Price, 50 cents per dozen; $\$ 3.00$ per 100 .

\section{PLUMBAGOS}

PLUMBAGO CAPENSIS -(Blue.) This produces large heads of light blue flowers. Has the most peculiar shade of blue of any flower in cultivation. Always in bloom and an elegant bedder. Price, 50 hundred.

PLUMBAGO CAPENSIS FLORA The exact counterpart of Plumbago Capensis, except in color, which in this beautiful novelty is a clear white. Do not confound this with the old worthless dozen; $\$ 4.00$ per hundred.

HARDY PLUMBAGO LADY LARPENT-GrowS in compact clumps and from the middle of .Tuly until severe frost is covered with lovely rich, vioiet-blue colored flowers. borne in close terminal heads. The foliage is unique, finely serrated and heartily recommend this fine variety for edging walks, beds and borders. Price, 50 cents per dozen; $\$ 3.00$ per hundred.

\section{SANSEVIERA ZEYLANICA}

Erect, rigid, sword-like leaves, in some old specimens reaching a length of from four to six feet. The leaves are thick and fleshy, a dark green color with clouded bars of white. Price, 50 cents per dozen; $\$ 4.00$ per hundred.

OXALIS ORTGIESI

It grows twelve to elghteen 1nches in helght, branching treely and loaded at all times with clusters of bright golden, star-shaped flowers, which do not close at night, llke ther Oxalis. Beautiful as the flowers are, it is still a splendid plant wlthout them, on account of its hlghly ornamental foliage. Prlce, 50 cents per dozen; $\$ 3.50$ per 100.

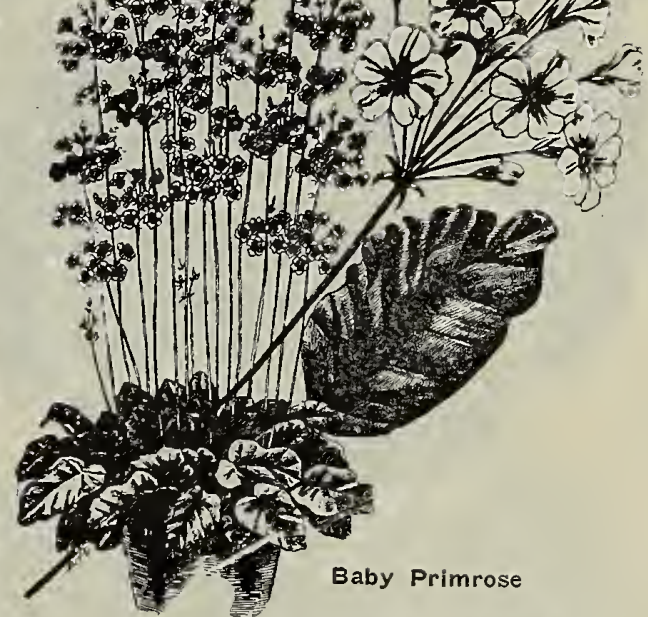

OTAHEITE DWARF ORANGE

$21 / 2$-Inch pot, 50 cents per dozen; $\$ 3.00$ per Strong 5-inch pot, $\$ 1.25$ per dozen; $\$ 12.00$

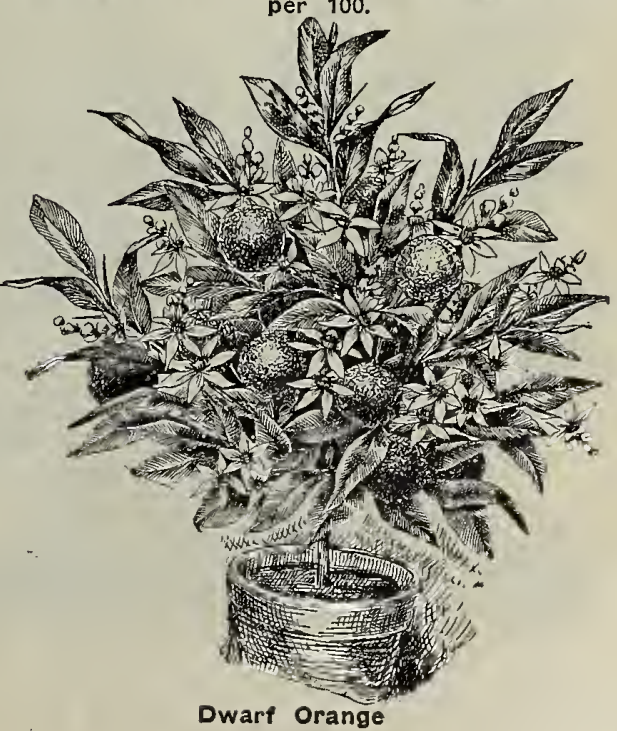




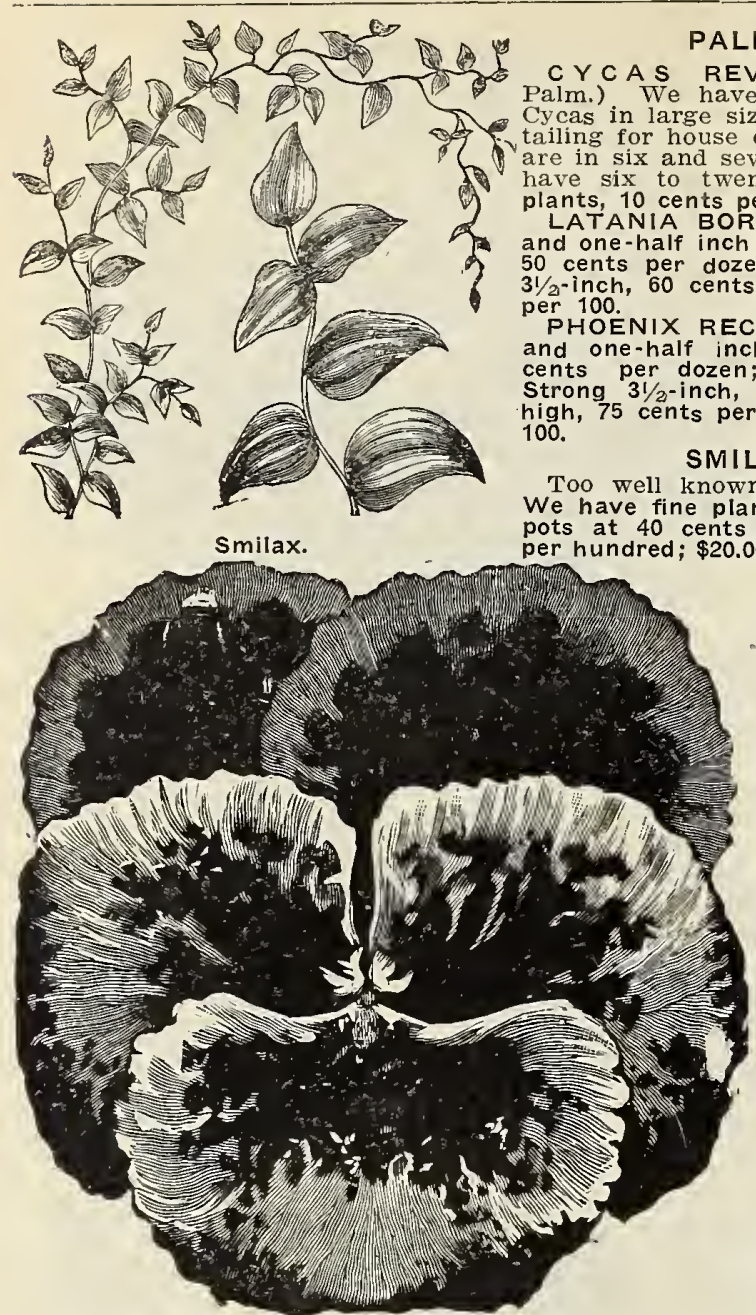

MCGREGOR'S NE $\because$ 'MAMMOTH PANSY

MCGREGOR' A splendid strain of Pansies. being a mixture of such sier They are fine transplanted plants. Price, 75 cents per hundred; $\$ 6.00$ per thousand.

SILVER-STRIPED PEPEROMIA

So thick and waxy-like are the leaves of this parlor gem that nearly everyone takes it to be an artificial plant. The leaves are distinctly variegated white and frosted silver. Price, 50 cents per dozen; $\$ 3.00$ per 100 .

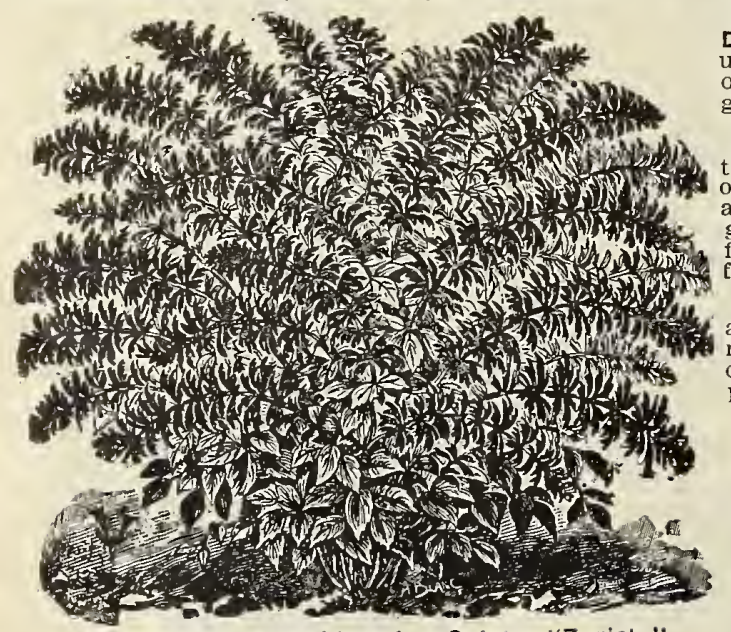

New Dwarf Ever-blooming Salvia, "Zurich."

Russelia Junea-This is the old Russelia. It is a beauty, and very valuable for baskets and vases.

\section{SALVIAS}

Price, 40 cents per dozen; $\$ 2.50$ per hundred, except where noted.

Dwarf Ever-Blooming Salvia ZURICH-A fine scarlet, very dwarf and an everfloomer, always in nower, a ering. Price, 50 cents per dozen; $\$ 3.00$ per hundred.

New Salvia, AUDUBONThe distinctive feature of strikingly handsome blotched foliage. The leaves are dark yellow wiotches sulphur or nearly all of the leaf. The intense bright scarlet flowers cents per dozen; $\$ 3.00$ per 100.

Spotted Salvia SILVERSPOT-In this new variety of Salvia the follage a very showy plant in summer. with long spikes of scarlet flowers.

ALBERT RAGNEAUThis variety we consider the best of dwarf varieties of fact, the only true dwarf one. The flower and foliage are the same as the old variety Splendens, but in making it more valuable for bordering beds, etc. S A L V I A SPLENDENS-The most popof scarlet flowers and green foliage.

ST. LoUIS-Claimed to be an improvement and growth. A very good variety; scarlet flower and green
foliage. ALBA-The same as Splendens in every respect except in color of flower,

\section{RUSSELIA} Rew Varieties)
R. Elegantissima Lemoinei Elegantissima-The primary stems 1 . graceful and arching in their form. The bloom $3 / 4$ th is so freely produced as to cover the plant. dozen: $\$ 3.00$ per 100

Lemoinei Multiflora-The primary stems strong and grassy. The flower panicles are extremely long, and are covered with tassels of fowers, one over the other color a grand coral-red. It is well named, "The Many-Fr $\$ 30$ cents per dozen; $\$ 3.00$ per 100.

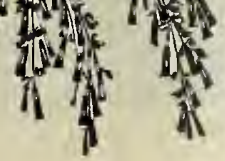




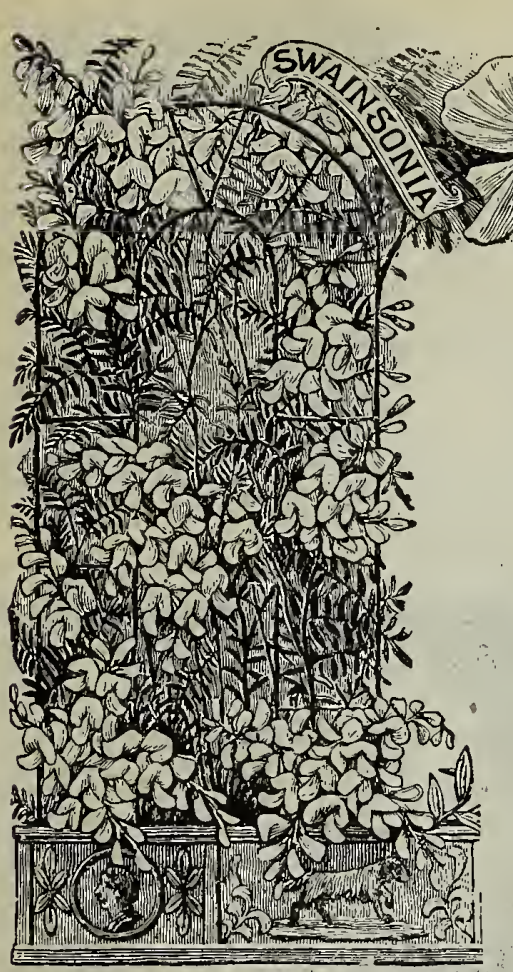

SWAINSONIAS

(White and Red.)

A native of Australia; extremely graceful; trained at a window or on a trellis presents a lovely sight of light green foliage,

and a splendid profusion of flowers resem-

bling Sweet Peas in form. White-Price,

Red-Price, $50 \mathrm{c}$ per doz.; $\$ 3.00$ per 100 .

\section{Hardy Perennial Plants \\ (Continued on page 22.)}

Many planters not thoroughly familiar with this class of plants have an idea that nothing but a large, field-grown clump will give satisfactory returns the first season. This, as experience has taught us, is in most instances a mistake. A vigorous plant of proper size will, in nearly every case, give, quicker and better re-
turns than the best so-called "field clumps" that can be procured.

$$
\text { BOSTON IVY-(Ampelopsis Veitchii) }
$$

This vine also goes under the name of "Japanese Ivy" and "Boston Ivy." It clings readily, to any surface, where it will spread its fairy-like tracery of infinite small leaflets and the accompanying cir$\$ 3.00$ per hundred.

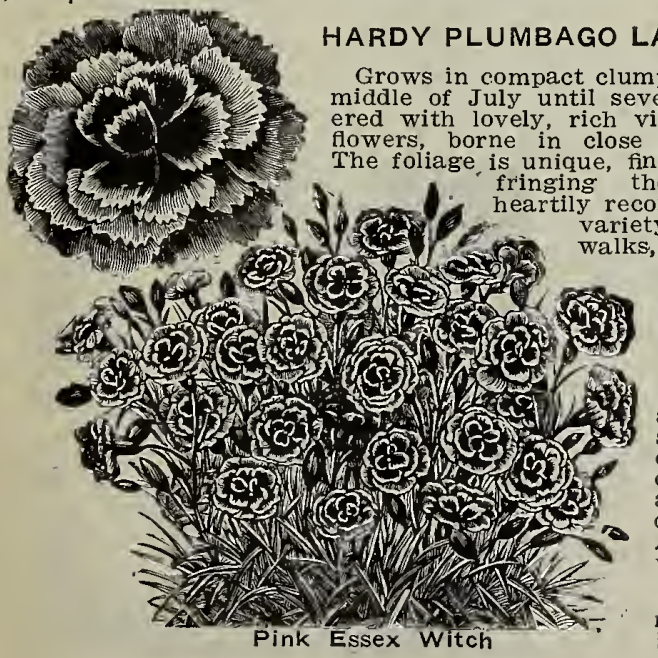

HARDY PLUMBAGO LADY LARPENT frost is covwith lovely, rich violet-blue colored The foliage, is unique, finely serrated and
fringing the stems. We

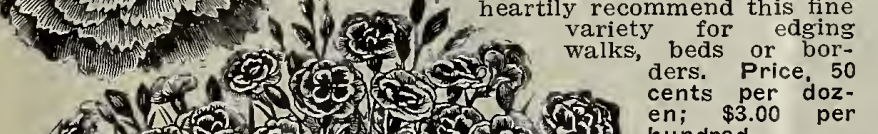
hundred.

TRITOMA-Red-Hot Poker A very attractive summer and autumn flowering plant, producing stately flower scapes and magnificent, dense terminal spikes of highcolored flowers, familiarly known on account of their shape and glowing colors as "Red-Hot Poker" plant. A very satisfactory hardy plant

Tritoma Pitzerii-The newest variety. Strong, field stock, price, $\$ 1.00$ per dozen; $\$ 8.00$ per 100 .
VINCAS

Strong 4-inch potted plants, 90 cents per dozen; $\$ 7.00$ per hundred; $31 / 2$-inch potted plants, 60 cents per dozen; $\$ 5.00$ per hundred; $21 / 4$-inch potted plants, 40 cents per dozen; $\$ 2.50$ per hundred.

This variety is far ahead of any other single violet known. The grand single flowers, of round, symmetrical in form. Price, $21 / 2$ inch It is the richest dark blue and very fra-
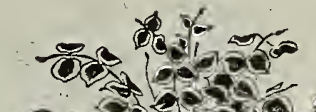

(1)

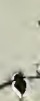

$-$

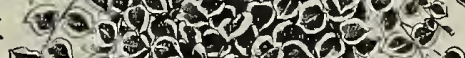

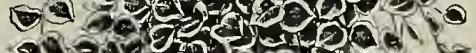

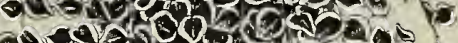

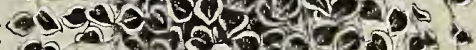

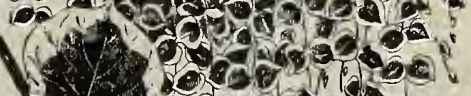

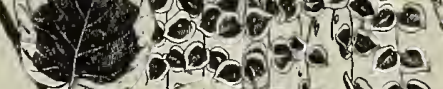

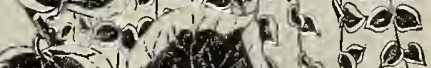

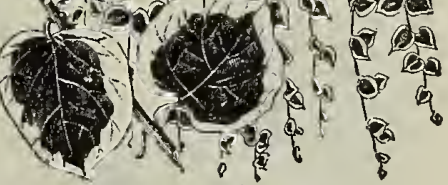

Vinca Major. Varlegata 


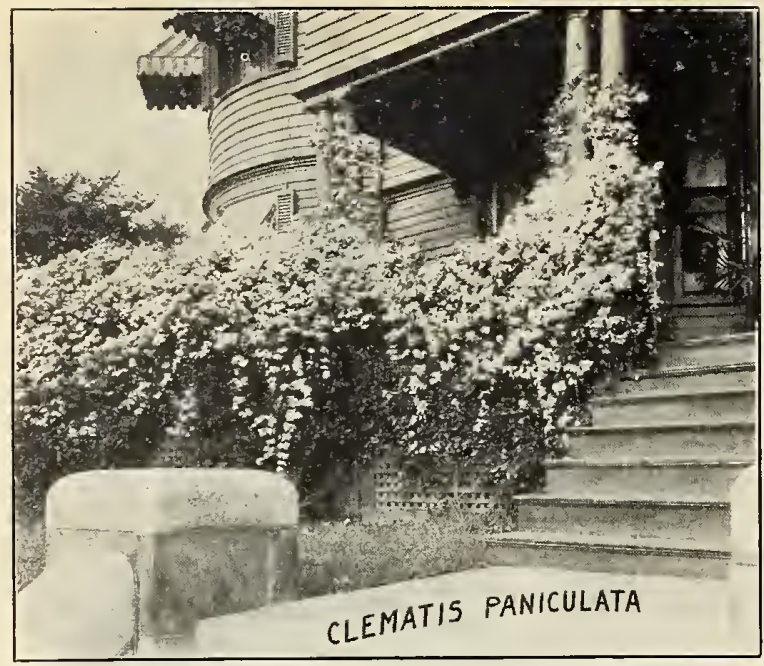

CLEMATIS PANICULATA
HARDY PHLOX

The plants we offer are all strong field grown plants with single stems. The varieties are day. Pink White Red, Purple Maroon, Variegated, etc. Our selection of varieties in six colors, such as Miss Lingard (white), Coquelicot (red), Prof. Schlieman (pink), Athis (salmon rose), and many other up-todate varieties. Strong $31 / 2$-inch pot plants, price, 60 cents per dozen; $\$ 5.00$ per hundred. Strong $21 / 2$-inch potted plants, 50 cents per dozen; $\$ 3.50$ per hundred. RUDBECKIA "Golden Glow"

A hardy perennial plant growing from four to six feet high branching freely, and bearing by the hundreds, on long, graceul stems, exquisite double blossoms of the brightest golden

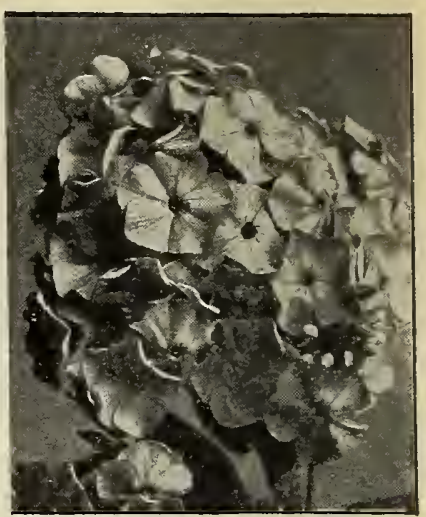
color and a Dahlias. Price D1/2-inch potted plants, $50 \mathrm{c}$ per
doz.; $\$ 4$ per 100.

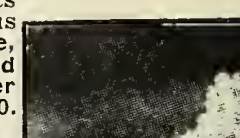

Phlox Coquelicot.

The Cluster-Flowered Clematis-The flowers are pure white, and are borne in great panicles or clusters of blooms. The indith ial hower is small white Price, strong field plants, 75 cents per dozen; $\$ 6.00$ per hundred $21 / 4$-inch pots, 50 cents per dozen; $\$ 3.00$ per 100 .

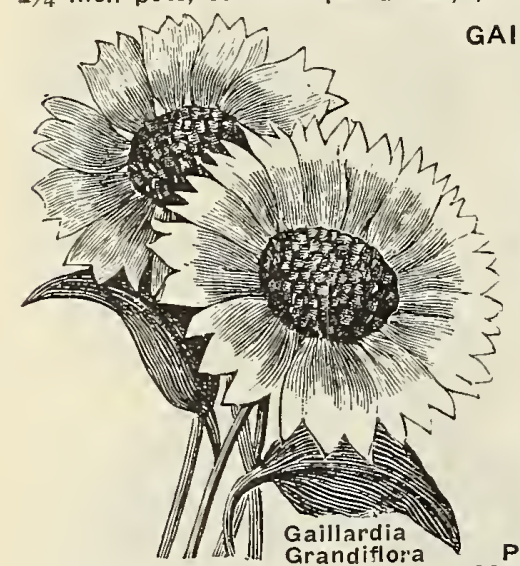

GAILLARDIA GRANDIFLORA

(Blanket Flower)

Of all hardy perennials perhaps the Gaillardia is the most satisfactory. Flowers are two to three inches in diameter, with. center of brownishred, while petals are shaded into Price, potted plants, 50 cents per dozen; $\$ 3.00$ per 100 .

\section{ACHILLEA THE PEARL}

The Great Cemetery Plant

Its flowers are pure white, perfect-

GYPSOPHILA

(Baby's Breath)

Paniculata-W $\mathrm{h}$ e $\mathrm{n}$ in September, it forms a symmetrical bloom during August ani height, and as much through, of minute pure white flowers, forming a beautiful gauze-like appearance. Price, 21/2-inch pot plants, 50 cents per dozen; $\$ 3.00$ per 100 .

HARDY AZALEA MOLLIS-(For Forcing)

The Azalea Mollis now holds a most important place, especially for the early winter months. Fine, bushy plants, fifteen to eighteen inches high, fifteen to twenty buds, 35 cents each; $\$ 4.00$ per dozen.

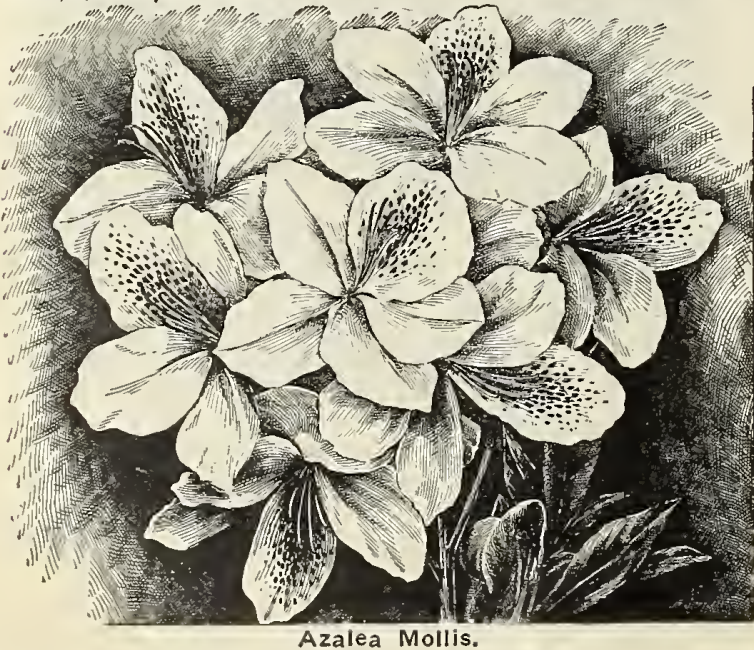

Azalea Mollis. sprays.

planting For cemetery valuable of anl flowers. Price, strong $31 / 2$-inch pot plants. 50 cents per dozen; $\$ 3.00$ per 100 .

HIBISCUS CRIMSON EYE

A fine large single

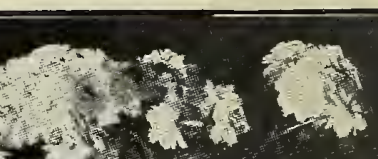




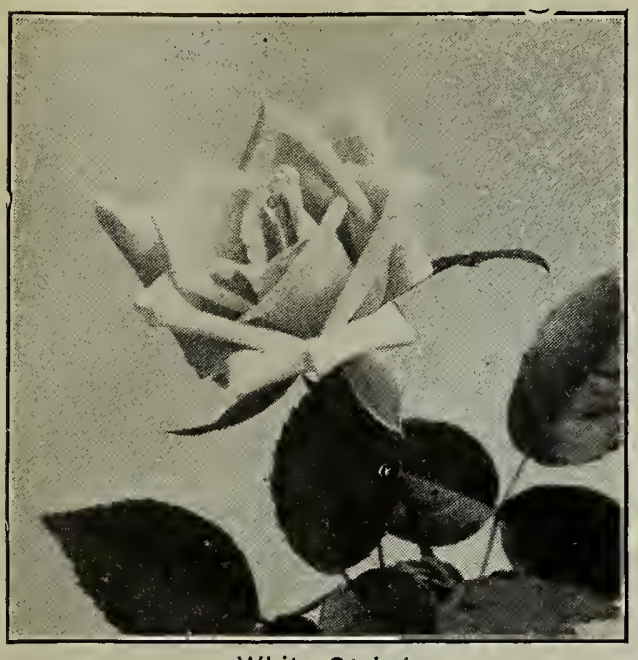

White cochet

\section{ROSES}

MADAME ABEL CHATENAY, Forcing Rose-Flowers large and full, petals recurved and of a beautiful creamy-rose, shaded with rose-vermilion and ting LA FRANCE-It is of superb form, and double as a Rose can be. Sil$\$ 27.50$ per 1,000 .

HELEN GOULD-(Baldwin)-Color intense carmine, with shades of cerise and solferino. Price, 50 cents per dozen; $\$ 3.00$ per $100 ; \$ 27 . \overline{0} 0$ per 1,000

Forcing Rose, KAISERIN AUGUSTA VICTORIA-This beautiful Rose is a continuous bloomer; color a pure snowy-white. Price, 50 cents per dozen; $\$ 3.00$ per $100 ; \$ 30.00$ per 1,000 . Strong, two-year-old plants, $\$ 1.00$ per dozen; $\$ 9.00$ per 100 .

New Rose, BESSIE BROWN-Hybrid Tea class and will stand frost if slightly protected. The color is a delicate light pink. A fine strong, free grower. Price, 50 cents per dozen; $\$ 3.00$ per $100 ; \$ 27.50$ per 1,000 .

The superb Yellow Rose, MARECHAL NIEL-A Rose so famous as to really require no description. Magnificent golden-yellow. Two-year-old plants of this variety are sold out. Price, $2 \frac{1}{2^{-i n c h,}} 50$ cents per dozen $\$ 3.00$ per $100 ; \$ 27.50$ per 1,000 .

ETOILE DE FRANCE-(Hybrid Tea.) A very strong, vigorous grower the flowers are very large and borne on good, long stiff stems; color the flowers are very large and borne on good, long stiff stems; color pots, 50 cents per dozen; $\$ 3.50$ per 100 .
"TAUSENDSCHON" (Hardy Climber) (J. S. Schmidt).-A beautiful new climber of the Crimson Rambler type, blooming from June 1 to August 1 . The flowers are about the size of clothilde soupert, soft pink, changing to rosy-carmine. Price, 50 cents per dozen; $\$ 3.50$ per hundred.

CLOTHILDE SOUPERT-The best market pot Rose. It is a strong, vigorous grower. The flowers are borne in sprays and the color blends from a soft shell-pink to a pure satinywhite rose. Price, 50 cents per dozen; $\$ 3.00$ per 100; $\$ 25.00$ per 1,000 .

BLUMENSCHMIDT-(Hybrid Tea.) Pure citron-yellow, outer petals edged tender rose, a sport from Franzisca Kruger, which it resembles in form, and which has a more vigorous growth. Price, $21 / 2$-inch pots, 50 cents per dozen; $\$ 4.0 J$ per 100
The Beautiful White Forcing Rose, WHITE MAMAN COCHET-Like its parent, the growth is vigorous, with rich, healthy foliage, producing large, fine flow ers of the purest
white. Price, 50 cents per dozen; $\$ 3.00$ per $100 ; \$ 25.00$ per 1,000 .

Forcing Rose, MAMAN COCHET-One of the best pink Roses. The color is deep rosy-pink. Price, 50 cents per dozen; $\$ 3.00$ per $100 ; \$ 25.00$ per 1,000 .

RHEA REID-The buds are long, oval and pointed, of a most beautiful rich crimson, and retain their form a long time. Of all the crimson Roses which have been introduced for years, there is none that has measured up better to the 50 cents per dozen; $\$ 3.50$ per 100 . Strong, two-year-old plants, $\$ 150$ per dozen: $\$ 1200$ per 100 .

\section{ROSES, TEAS AND HYBRID TEAS}

The following list, $21 / 2$-inch pot plants, price 50 cents per dozen; $\$ 2.50$ per $100 ; \$ 22.50$ per 1,000 . Strong, two-year-old plants, $\$ 1.00$ per dozen; $\$ 8.00$ per 100 .

ELISE HEYMANN-The color is light yellow, shaded with nankeen-yellow, center rosy-peach. Vigorous growth and fine foliage.

GOLDEN GATE-It is a strong, healthy grower. Produces a profusion of long, pointed buds, opening to very large doua profusion of long, pointed buds, opening to very large doulow at the base of the broad petals, which are exquisitely bordered with clear rose.

The New Bedding Rose, GRUSS AN TEPLITZ-When first opened it is a rich, dark crimson, quickly changing to a velopened it is a
vety fiely-red.

GENERAL DE TARTAS-A brilliant carmine, deeply shaded with violet. An extra large Rose, of good shape.

MADAME SCHWALLER-Large globular flowers, color transparent salmon-rose; petals finely edged with violet-carmine; highly perfumed. One of the easiest to grow.

MARIE LAMBERT-Pure white. It has been called the White Hermosa, as it resembles Hermosa in form and freedom of bloom, and is quite as valuable.

LA PRINCESS VERA-The color of this variety is a creamy-rose, veined with lilac; large and full.

MRS. B. R. CANT-A fine garden variety of even shade of bright rose, round and full, the form of a good H. P. A very free grower and free bloomer.

MRS. DE GRAW-In color it is a rich, glossy pink, delightfully fragrant, and is a strong, vigorous grower.

PAPA GONTIER-The blooms are large and long, with thick and broad petals of dark carmine-crimson.

QUEEN'S SCARLET-Cherry-red flowers. Very free bloomer and strong grower.

SAFRANO-One of the best of all coppery-colored varieties; growth is very vigorous, flower large, yellow margin shading to a deep copper.

THE QUEEN-A most charming Tea Rose, the offspring of that fine old Rose, Souvenir d'un Ami. It is pure snowwhite, makes good buds, is quite full, showing the center but
slightly.
COQUETTE DE LYON-A fine yellow ROse, large, very attractive.

DUCHESSE DE BRABANT-A bright China Rose, with coppery-yellow center, ends of petals suffused with carmine.

ETOILE DE LYON-This is considered one of the finest yellow bedding Roses for outside planting; it is, moreover, one of the hardiest in the Tea section.

CATHERINE MERMET-Color silvery-rose to the exquisite combination of yellow and rose.

PRINCESS SAGAN-Flowers of this variety are the richest crimson of any Rose in our vast collection.

MARIE GUILLOT-This variety holds first place among white Tea Roses in purity of color; grows well and is healthy. METEOR-A velvety-red ever-bloomer of the deepest glowing crimson.

MLLE. FRANZISCA KRUGER-The striking color of this deep coppery-yellow it stands distinct from all others.

MADAME LOMBARD-This great Southern Rose is classed among the best of pink varieties for garden planting or pot culture.

The Superb New. Tea Rose, ANTOINE RIVOIRE-A handsome new Rose with large, full, Camellia-shaped flowers. Color rosy-flesh on a yellow ground, shaded with a border of carmine.

AGRIPPINA-An old standard. Flowers red; vigorous grower and free bloomer.

BRIDE-Beautiful white Tea Rose. The flowers are very arge and double on long sitiff stems.

Forcing Rose, BRIDESMAID-This variety is grown so extensively now that it hardly needs description. It is a deep pink.

BURBANK-A free-flowering ever-blooming Rosc, flowers very profusely; color light pink.

LA MARQUE-Large full flowers, borne in large clusters, ure white and double. A rampant climber.

LUCULLUS-A fine, dark crimson. It is very double and constant bloomer. 


\section{L I M B I N G TEA R OSES}

Price, 50 cents per dozen; $\$ 3.00$ per $100 ; \$ 25.00$ per 1,000 rowing and vigorous Climbing Roses we have ever seen. The flowers are extra large, deep and double.

CLIMBING BRIDESMAID-The flowers are simply beautiul (identical with Bridesmaid). A clear, dark pink.

CLIMBING METEOR-It is the acme of all red Climbing Roses. It is a free, persistent bloomer.

CLIMBING BRIDE, or Ruth Vestal-A very strong grower; sport from the well known Rose Bride throwing out thick nes and bearing large, pure snow-white flowers.

EMPRESS OF CHINA-Here we have a Rose that blooms continuously for over seven months in the year. When it
first opens the flowers are a beautiful red, but soon turn to a lovely light pink.

CLIMBING WHITE PET-This is an unusually vigorous grower. The flowers are very double and full, of medium STRIPED REINE MARIE HENRIETTE-(Climbing Tea.) A sport from the old favorite Reine Marie Henrietta, has the beautifully striped, flamed and shaded in bright carmine over pale rose.

REINE MARIE HENRIETTE-An excellent crimson-flowered ever-blooming climber. The flowers are exquisitely formed, very full and double, nicely tea-scented; strong growing and very free flowering.

MARY WASHINGTON-It is a lovely Rose and usually comes in large clusters of the purest white and very fragrant. SOLFATARE-Fine, clear sulphur-yellow; large, double, JAMES SPRUNT-A grand Rose. Deep cherry-red.

CLIMBING CLOTHILDE SOUPERT-Identical with Clothilde Soupert, except it is a rapid climber.

WILLIAM ALLEN RICHARDSON-A beautifully colored and very free blooming Rose of vigorous growth; color and very free blooming Rose of vigorous growth;

\section{Hardy Climbing Roses}

CRIMSON RAMBLER-One of the striking characteristic of this Rose is its remarkable color, which is of the brightest crimson. Flowers produced in great pyramidal panicles, or 50 cents per dozen; $\$ 3.00$ per hundred; $\$ 25.00$ per thousand Strong, two-year-old plants, $\$ 1.00$ per dozen; $\$ 8.00$ per hundred. Three-year-old field grown, $\$ 1.50$ per dozen; $\$ 12.00$ per

PHILADELPHIA RAMBLER-It is very free both in growth and bloom, and will be found a splendid addition to the Crimson Rambler section. Price, 50 cents per dozen old plants, $\$ 1.00$ per dozen; $\$ 8.00$ per hundred. Three-year old, field grown, $\$ 1.50$ per dozen; $\$ 12.00$ per hundred.

PINK RAMBLER-A new Rose from the Crimson Rambler which is identical with its parent in all its fine qualities except the color, which is a light salmon-rose shaded with pink. Strong grower and a real companion to Crimso

WHITE RAMBLER-A blood relative to the popular Crimson Rambler and identical to it in hardiness and flowering qualities. A good Rose to train on the trellis or to cover unsightly fences. Flowers of pure white, come in clusters, dozen; $\$ 2.50$ per hundred.

dozen; $\$ 2.50$ per hundred. low; the flowers are very sweet scented; habit of growth is very vigorous, well-established plants often making shoots
from eight to ten feet in height in a single season. Price, 50 cents per dozen; $\$ 2.50$ per hundred.

\section{Hardy Climbing* Prairie Roses}

Price, 50 cents per dozen; $\$ 2.50$ per hundred.

TENNESSEE BELLE-Flowers bright, beautiful pink. Is more slender and graceful in growth than any of the other

BALTIMORE BELLE-Pale blush. variegated carmine ose and white, very double. Flowers in beautiful clusters. ers. varies in color from white to crimson. culiar globular form. Bright rosy-red, changing to lighter as the flower opens. Of very strong, rapid growth.

MRS. GUNNEL-Soft, rosy-blush, becoming almost white;

large clusters; full and double. rose center; large clusters, very double.

\section{HYBRID PERP}

Price, 50 cents per dozen; $\$ 3.50$ per 100 (except wher PAUL NEYRON-Deep, shining rose, very fresh and pretty, flowers very large, often measuring five inches in diameter. We know of no Rose possessing so

ROGER LAMBELIN-One of the most remarkable Roses yet offered. The petals are irregular on the edges, like a double Petunia; the color is glowing crimson throughout, with a white band, forming a sharp contrast and the most unique combination of colors known in Roses. Price, 60 cents per dozen; $\$ 4.00$ per hundred.

ANNA DE DIESBACH (Glory of Paris)-Bright pink, long, pointed buds and large, finely formed, compact flower, vel. ull and double and delightful and sweet.

BALL OF SNOW (Boule de Neige)-Hybrid Noisette. A when first opening. Price, $\$ 3.00$ per hundred.

GIANT OF BATTLES-This is still esteemed as the very
GIAN best rich, red Rose; very large, double, full and sweet; exGENERAL JACQUEMINOT-Bright red, fragrant, extra. This is too well known to need description.

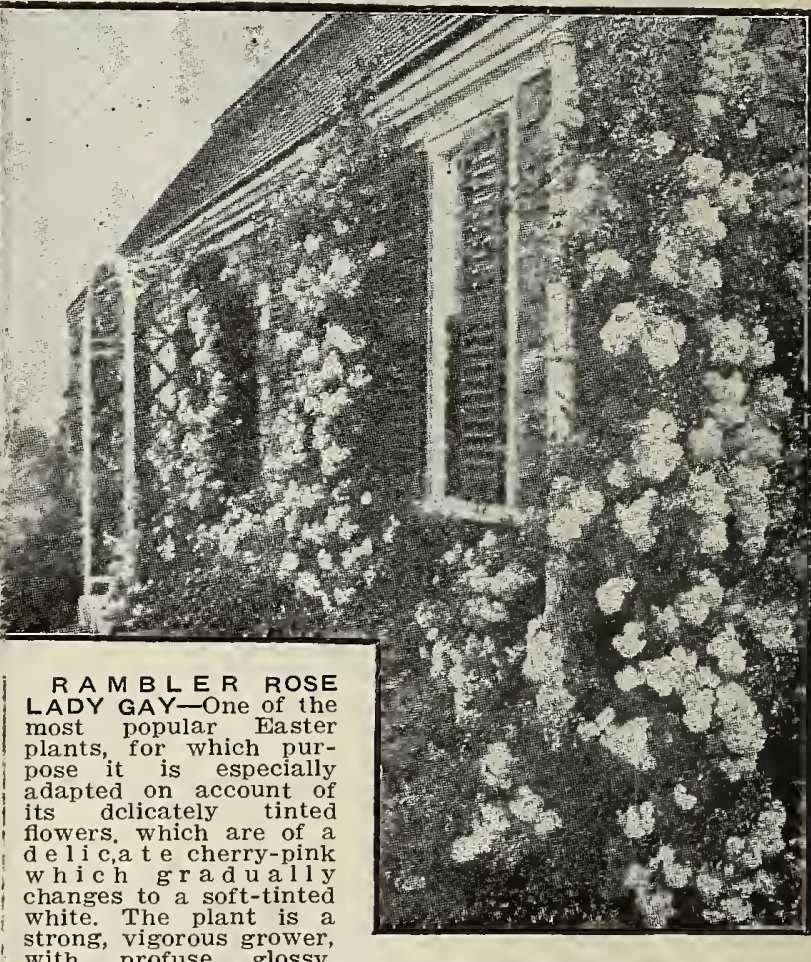

with profuse glossy,

deep green foliage. Price, 50 cents per dozen; $\$ 3.00$ per hun$\$ 1.00$ per dozen; $\$ 8.00$ per hundred.

DOROTHY PERKINS-Beautiful shell-pink. A rapid grower, frequently developing shoots from ten to fifteen feet long in one season. Hardy, withstanding the severest winters Price, 50 cents per dozen; $\$ 3.00$ per hundred. Two-year-old plants, $\$ 1.00$ per dozen; $\$ 8.00$ per hundred.

\section{GTUAL ROSES}

soted). Four-inch pots, $\$ 1.50$ per dozen; $\$ 12.00$ per 100

MADAME CHARLES WOOD-A true perpetual bloomer the flowers are large, very double and full and quite fragrant; color a bright cherry-red.

CLIO-This variety is of very vigorous growth, and has large, handsome foliage; the flowers are flesh color, shaded the center with rosy-pink.

DINSMORE - Cherry-red, fragrant, good bloomer, moderate

DUKE OF EDINBURG-One of the old standby bright red
DUKE like Madame Chas. Wood. Roses for the garden.

PRINCE CAMILLE DE ROHAN-This variety is always a rime favorite with everybody; the richest crimson.

MADAME MASSON-An excellent Hybrid Perpetual, noted for its constant and profuse bloom; the flowers are large, color a clear bright red, highly perfumed.

MADAME PLANTIER-This is the old favorite June Rose. Vigorous grower; as hardy as an oak; pure white double lowers; very fragrant. Price, $\$ 3.00$ per 100 .

VICK'S CAPRICE-This is the only hardy Rose that has any variegation. It is a vigorous grower, and bears large and fragrant flowers of bright rose distinctly striped with 